Full Length Article

\title{
Revised conceptualization of the North China Basin groundwater flow system: Groundwater age, heat and flow simulations
}

\author{
Guoliang Cao ${ }^{\mathrm{a}, \mathrm{b}}$, Dongmei Han ${ }^{\mathrm{c}, *}$, Matthew J. Currell ${ }^{\mathrm{d}}$, Chunmiao Zheng ${ }^{\mathrm{e}, \mathrm{f}}$ \\ a State Key Laboratory of Simulation and Regulation of Water Cycle in River Basin, China Institute of Water Resources and Hydropower Research, Beijing 100038, China \\ ${ }^{\mathrm{b}}$ National Centre for Groundwater Research and Training, Adelaide, SA, Australia \\ ${ }^{\mathrm{c}}$ Key Laboratory of Water Cycle E' Related Land Surface Processes, Institute of Geographic Sciences and Natural Resources Research, Chinese Academy of Sciences, \\ Beijing 100101, China \\ d School of Civil, Environmental and Chemical Engineering, RMIT University, Melbourne 3001, Australia \\ e School of Environmental Science and Engineering, South University of Science and Technology of China, Shenzhen, China \\ ${ }^{\mathrm{f}}$ Department of Geological Science, University of Alabama, Tuscaloosa, AL, USA
}

\section{A R T I C L E I N F O}

\section{Article history:}

Received 15 February 2016

Received in revised form 13 May 2016

Accepted 25 May 2016

Available online 8 June 2016

\section{Keywords:}

North China Basin

Groundwater flow system

Groundwater age

Hydrodynamic stagnant groundwater

\begin{abstract}
A B S T R A C T
Groundwater flow in deep sedimentary basins results from complex evolution processes on geological timescales. Groundwater flow systems conceptualized according to topography and/or groundwater table configuration generally assume a near-equilibrium state with the modern landscape. However, the time to reach such a steady state, and more generally the timescales of groundwater flow system evolution are key considerations for large sedimentary basins. This is true in the North China Basin (NCB), which has been studied for many years due to its importance as a groundwater supply. Despite many years of study, there remain contradictions between the generally accepted conceptual model of regional flow, and environmental tracer data. We seek to reconcile these contractions by conducting simulations of groundwater flow, age and heat transport in a three dimensional model, using an alternative conceptual model, based on geological, thermal, isotope and historical data. We infer flow patterns under modern hydraulic conditions using this new model and present the theoretical maximum groundwater ages under such a flow regime. The model results show that in contrast to previously accepted conceptualizations, most groundwater is discharged in the vicinity of the break-in-slope of topography at the boundary between the piedmont and central plain. Groundwater discharge to the ocean is in contrast small, and in general there are low rates of active flow in the eastern parts of the basin below the central and coastal plain. This conceptualization is more compatible with geochemical and geothermal data than the previous model. Simulated maximum groundwater ages of $\sim 1$ Myrs below the central and coastal plain indicate that residual groundwater may be retained in the deep parts of the basin since being recharged during the last glacial period or earlier. The groundwater flow system has therefore probably not reached a new equilibrium state with modern-day hydraulic conditions. The previous hypothesis that regional groundwater flow from the piedmont groundwater recharge zone predominantly discharges at the coastline may therefore be false. A more reliable alternative might be to conceptualize deep groundwater below the coastal plains a hydrodynamically stagnant zone, responding gradually to landscape and hydrological change on geologic timescales. This study brings a new and original understanding of the groundwater flow system in an important regional basin, in the context of its geometry and evolution over geological timescales. There are important implications for the sustainability of the ongoing high rates of groundwater extraction in the NCB.
\end{abstract}

(c) 2016 Elsevier Ltd. All rights reserved.

\footnotetext{
* Corresponding author.

E-mail address: handm@igsnrr.ac.cn (D. Han).
}

\section{Introduction}

\subsection{Regional groundwater flow in sedimentary basins}

The gravity driven multiple-scale groundwater flow systems theory derived by Tóth (1963) is widely regarded as the paradigm for the modern study of regional groundwater flow (e.g., Lazear, 
2006; Cardenas, 2007; Gleeson and Manning, 2008; Schaller and Fan, 2009). Topography and groundwater table configurations determine the regional groundwater flow pattern, and therefore greatly affect the migration of solutes and convective heat transfer (e.g., Banner et al., 1989; Deming et al., 1992; Garven, 1995; Tóth, 1999). Many previous studies have examined how the topography/ recharge controlled groundwater table configurations affect multiple-scale flow patterns (e.g., Haitjema and Mitchell-Bruker, 2005; Gleeson and Manning, 2008). Generally speaking, the combined effects of hydraulic characteristics (e.g., hydraulic conductivity), recharge rates, the geometric dimensions of the aquifer, and the relative positions of the recharge and discharge zones determine the dominant flow pattern. Using topography solely may lead to misunderstanding of groundwater flow system dynamics and thus problematic conceptualizations. It is therefore necessary to integrate information with respect to all of the controlling factors-including heterogeneous aquifer properties (e.g., Freeze and Witherspoon, 1967), influence of geological structure, and changes in boundary conditions due to geological and geomorphological evolution (e.g., Lemieux et al., 2008)-to more realistically evaluate the groundwater flow regime.

Groundwater flow regimes in regional systems result due to long-term transient responses to climate change and/or tectonic movements (Tóth, 2009; Schwartz et al., 2010). As aquifer pressure transfer is generally much faster than actual groundwater flow, the reliability of the premise of quasi-steady state under a specific hydraulic condition should be evaluated in a given timescale relevant to the size of the basin, considering the impact of past sealevel, climatic and tectonic evolution (Garven, 1995). In the absence of information allowing transient simulation of the flow system on geological time scales, groundwater residence time indicators in the aquifer can be used to constrain the time scales relevant to the groundwater currently existing in the aquifer, and help to understand the evolution of the system (e.g., Morrissey et al., 2010). Combining such information with groundwater age simulations may prove a powerful new approach to explore the dynamics and evolution of regional groundwater flow systems over geological timescales (e.g., Lemieux et al., 2008; Gupta et al., 2015). Groundwater age (or residence time) is the average time elapsed since recharge of the range of water molecules present in a sample, integrating the effects of advection, hydrodynamic dispersion and mixing (Goode, 1996; Bethke and Johnson, 2002; Massoudieh et al., 2012). Under flat topography in coastal plain areas, groundwater flow will be dominated by downdip horizontal flow along the axis of the aquifers, and ground water age generally show an increasing trend toward coast (e.g., Kennedy and Genereux, 2007; Schaller and Fan, 2009; Plummer et al., 2012; Stewart, 2012).

\subsection{Previous conceptual model of regional groundwater flow in the North China Basin}

The North China Basin (NCB) (also called Bohai Bay Basin), which includes the North China Plain (NCP) and the Bohai Bay, was developed on Archeozoic metamorphic basement. The NCP is the largest plain in east Asia, occupying an area of $140,000 \mathrm{~km}^{2}$ in northeast China. It consists of numerous alluvial fans and alluvial plains extending from the Taihang Mountains on the west and Yanshan Mountains on the north, to the Bohai Bay in the east (Foster et al., 2004) (Fig. 1a). Several distinct phases of rifting and subsidence since Mesozoic and Cenozoic era resulted in a series of uplifts and depressions primarily trending to the northeast, creating a low-high-low tectonic framework (Ye et al., 1985) (Fig. 1b). The basin consists of a series of Paleozoic, Mesozoic, and Cenozoic sediments; and the continuous deposition process since the Neogene period resulted in as much as $2500 \mathrm{~m}$ of Neogene and Quaternary sediments covering the older basement (Fig. 2). Migration of oil and transfer of heat have been shown to be strongly related with groundwater flow in the basin (Chen, 1988). A reasonable and reliable conceptual model for groundwater flow in the basin is important for sustainable usage of groundwater (including thermal water) as well as oil, gas and salt/brine.

Conceptualization of the groundwater flow system built on previous studies is based on two primary premises: (1) the Neogene deposits act as a low-permeability aquitard below the Quaternary aquifers; (2) groundwater in the Quaternary aquifers is in a quasi-equilibrium state with the modern landscape and hydraulic conditions. Under these hypotheses, the groundwater flow patterns were inferred based on topographic relief and water table configurations (see Fig. 1a); and a regional groundwater flow system was proposed extending throughout the Quaternary sediments (Fig. 3) in the basin, traveling a distance of $\sim 300 \mathrm{~km}$ from the mountainous areas in the west and north to the Bohai Bay in the east (Fig. 4) (Zhang and Payne, 1987; Zhang et al., 2000; Chen et al., 2005). However, this conceptualization of the groundwater flow regime was assumed without a systematic analysis of recharge/discharge distribution, hydraulic continuity (between different provinces of the basin) and assessment of the timescales of flow. Groundwater flow patterns are highly related with the depth of the basin, with deep basins theoretically generating a greater vertical component of flow under the same flow-inducing forces (Tóth, 1963; Freeze and Witherspoon, 1967). In the NCB, the ratio of thickness of the Quaternary aquifer to the width of the generally inferred regional flow system is about $1 / 500$, suggesting a very shallow basin with limited potential to generate vertical components of flow and thus local discharge points across the basin. However, the underlying impermeable Pre-Cambrian basement reaches a depth of up to $10 \mathrm{~km}$ (Yang and $\mathrm{Xu}, 2004$ ), and there is a substantial thickness of Neogene sediments underlying the Quaternary aquifers which may be important in the flow system. After decades of hydrogeological investigations and data collection in the NCB, the hydrological and in particular geochemical datasets (e.g., radio-isotope tracers) have been shown to conflict with the inferred flow regime of this conceptual model (see Section 2.3). As a reliable conceptual model is crucial for groundwater development (e.g., Gillespie et al., 2012), this makes it necessary to re-assess and revise the previously constructed groundwater conceptual model and explore alternative hypotheses.

\subsection{Aims of this study}

As the hypothesis of the regional horizontal groundwater flow regime under modern hydraulic conditions has failed to explain the regional stable and radiogenic isotope data, the originally developed conceptual model of groundwater flow in the NCB needs to be re-examined, integrating information on the basin geometry, aquifer heterogeneity and climatic/geomorphological/geological evolution. The primary objectives of this study are:

1. Evaluate the impact of different combinations of hydraulic parameters and boundary conditions on groundwater flux, flowpaths, groundwater age distributions and heat transport in the NCB.

2. Use coupled groundwater flow and solute transport modeling to estimate theoretical maximum groundwater ages under modern hydraulic conditions, thus constraining the timescale required for the basin to reach a 'quasi-steady state' with prevailing landscape and hydrological/climate conditions. 


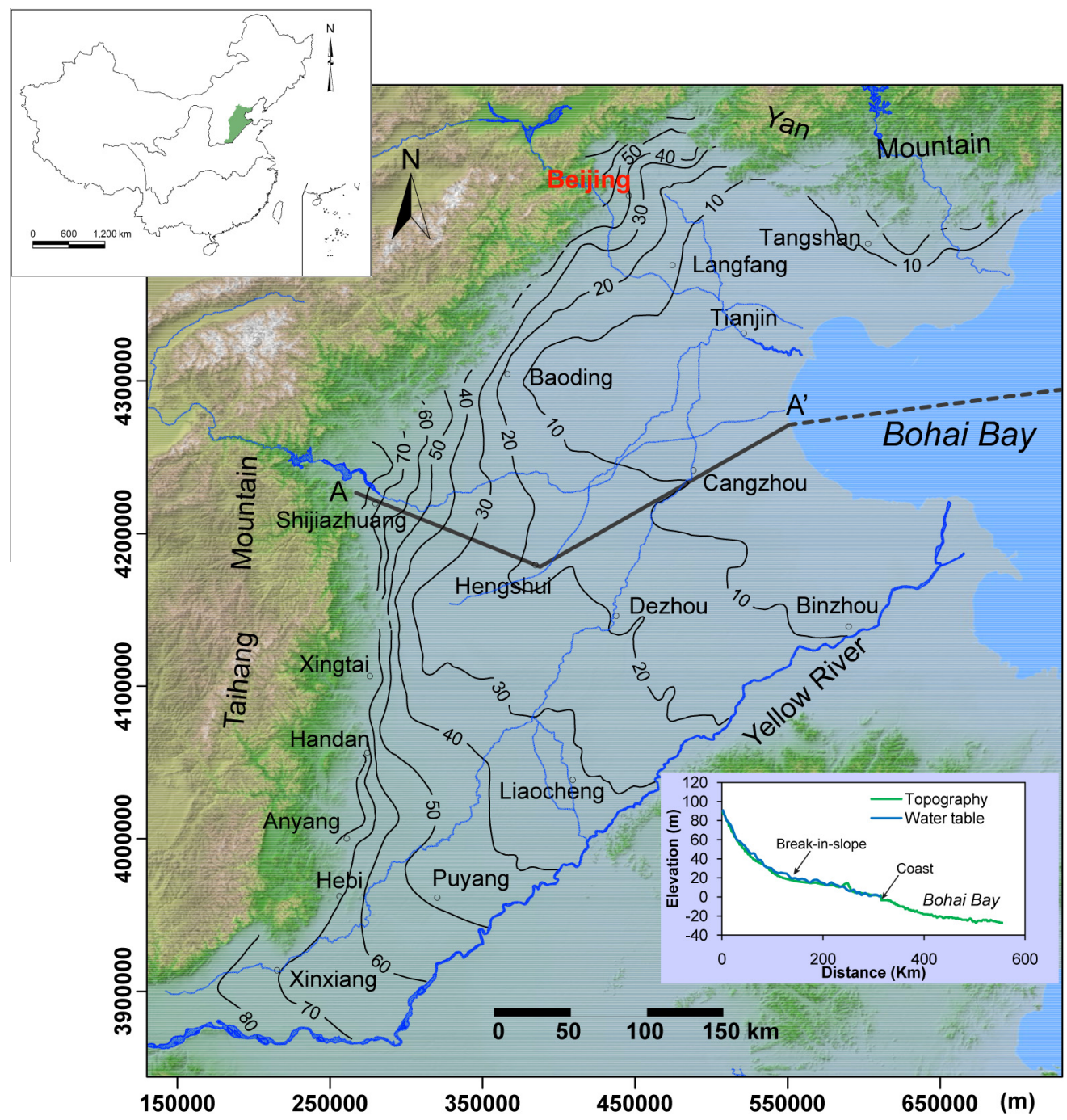

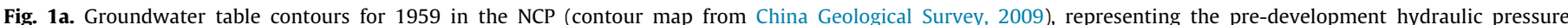

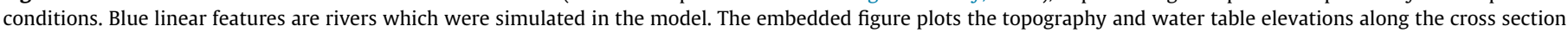

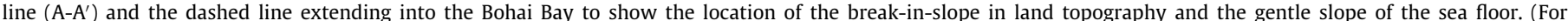
interpretation of the references to color in this figure legend, the reader is referred to the web version of this article.)

3. Re-assess the flow regime and determine an alternative regional conceptual hydrogeological model for groundwater and heat flow in the basin which we believe is more fitting with chemical, isotopic and other geological data presented in the past.

\section{Geological setting}

\subsection{Tectonics and basement structure}

The NCB underwent several distinct phases of rifting and subsidence during the Cenozoic era. The last major phase began during the early Tertiary. Active rifting had slowed and gradual subsidence begun by the late Tertiary period (Ye et al., 1985). The regional rifting resulted in a series of uplifts and depressions containing numerous smaller secondary uplifts and depressions within the basin (Xu et al., 1996). These include: the Jizhong depression, the Cangzhou and Neihuang uplifts, the Huanghua and Linqing depressions, the Chengning uplift and the Jiyang depression (Fig. 1b). Faulting and subsidence continued through the Quaternary, resulting in a combined thickness of 1000-2500 m of Neogene and Quaternary sediments, with significant variability in thickness from west to east (Fig. 2). With the increase/decrease in aquifer thickness, the overall groundwater balance must be closed by either reduction/increase in horizontal velocity or inflow/outflow in the vertical or lateral directions. The alternation of depressions and uplift in the basement structure may have substantial effects on groundwater flow patterns in this context.

\subsection{Quaternary and Neogene aquifers}

The Quaternary sediment depth and sedimentation rates are greater in depressions than over uplifted sections (Xu et al., 1996). The thickness of the Quaternary sediments decreases from $600 \mathrm{~m}$ in the central Hebei depression to only $200-350 \mathrm{~m}$ over the Cangzhou and Neihuang uplifts (Xu et al., 1996). The thickness of the Quaternary sediments are $450-550 \mathrm{~m}, 350-375 \mathrm{~m}$, and $350-450 \mathrm{~m}$ in the Huanghua depression, and over the Chengning uplift and in the Jiyang depression, respectively (Xu et al., 1996). The Quaternary aquifers are traditionally divided into four major aquifer units often referred to as aquifer I, II, III and IV (Fig. 3). The corresponding geologic units are Holocene series $\left(Q_{4}\right)$, and late $\left(Q_{3}\right)$, middle $\left(Q_{2}\right)$ and early $\left(Q_{1}\right)$ Pleistocene series, respectively (e.g., Zhu et al., 1995; Foster et al., 2004). The Quaternary aquifers 


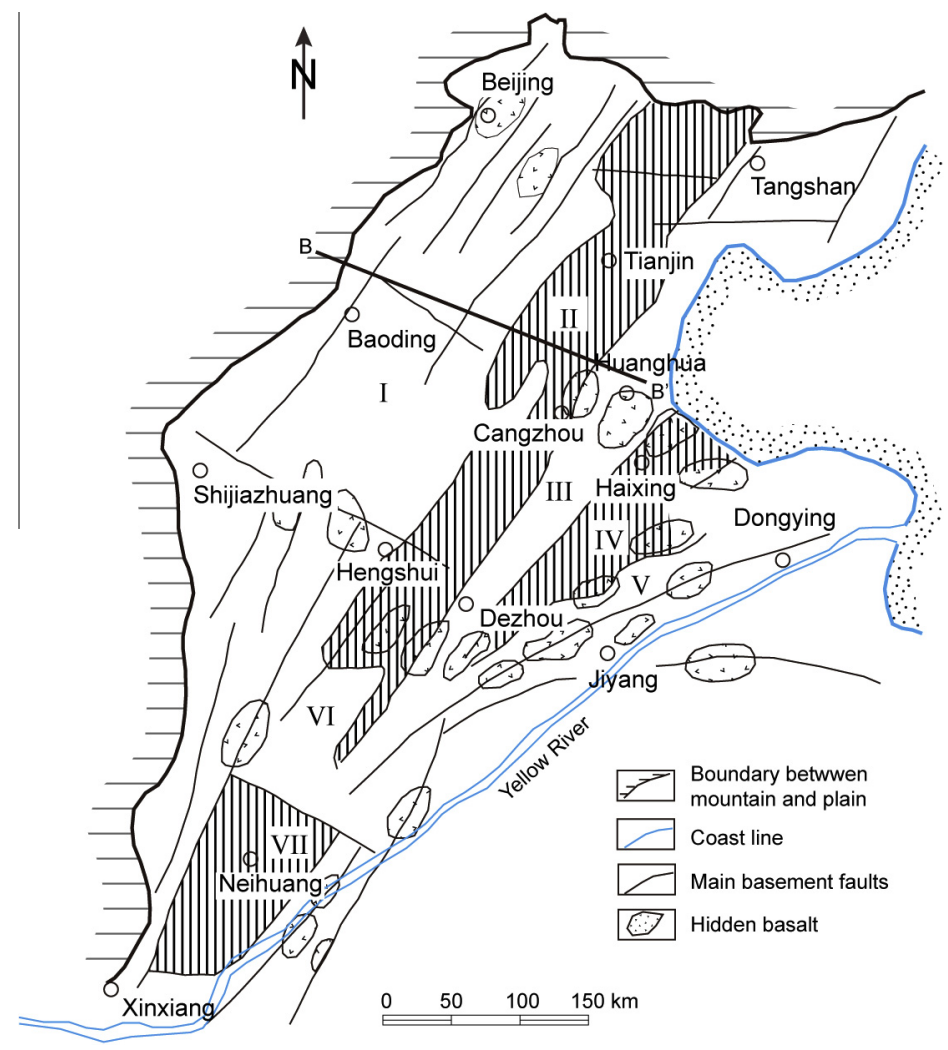

Fig. 1b. Structural architecture of the NCB (from Sun and Niu, 2000). (I) Jizhong depression, (II) Cangxian uplift, (III) Huanghua depression, (IV) Chengning uplift, (V) Jiyang depression, (VI) Linqing depression, (VII) Neihuang uplift.

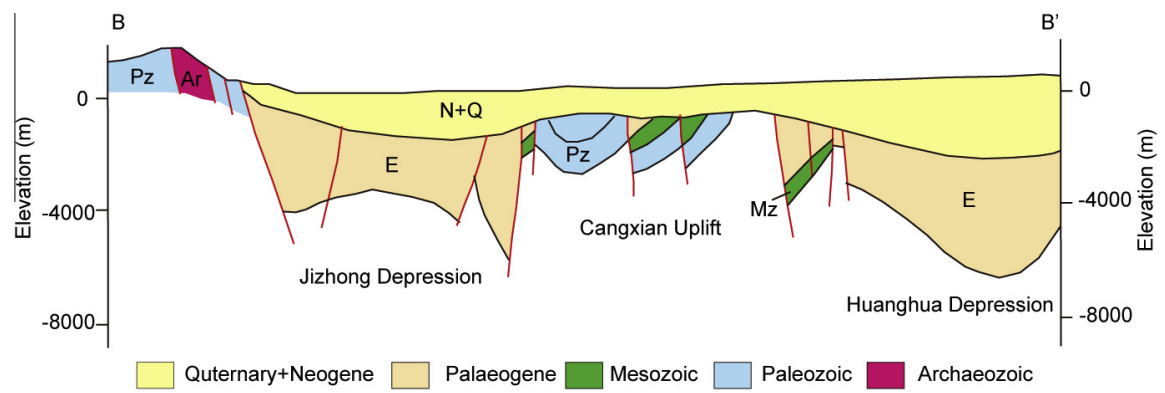

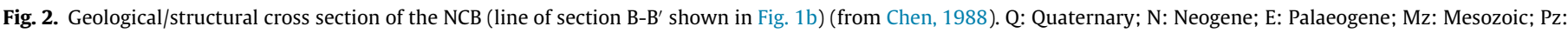
Paleozoic; Ar: Archaeozoic. The major tectonic/structural provinces underlying the basin are shown.

are unconfined in the piedmont region and are mainly fed by precipitation infiltration and lateral flow, becoming semi-confined and confined by multiple clay layers toward the central and coastal plains. This setting is typical of many alluvial aquifers in which the sediments are sourced from upstream mountainous areas. Shallow groundwater is frequently characterized by high levels of mineralization over the central and eastern plains (Fig. 4). The area of water with total dissolved solids (TDS) $>1 \mathrm{~g} / \mathrm{L}$ in the shallow aquifer is $\sim 80,000 \mathrm{~km}^{2}$, which accounts for $\sim 60 \%$ of the plain. Additionally, it has been shown that the aquifer system contains a number of horizons of brackish, low quality water, in which high concentrations of fluoride occur (Wen et al., 2013).

The Neogene sediments consist of alluvial sandstone interbedded with clay, with a thickness of 1200-2000 m, and bottom depth of $1500-2500 \mathrm{~m}$. The temperature of the geothermal water in the sediments reaches $30-85^{\circ} \mathrm{C}$, with TDS generally less than $3.0 \mathrm{~g} / \mathrm{L}$, and it has become a primary geothermal water production source. The hydraulic conductivity of the Neogene sandstones ranges from
0.5 to $2.6 \mathrm{~m} / \mathrm{d}$, and exhibit a nearly exponential decrease with depth (Chen, 1988).

The Paleogene sediments were deposited to thicknesses of $5000-7000 \mathrm{~m}$. The Paleogene sequences act as a trap for the hydrocarbon source rocks beneath and are the primary oil production zone in the basin (Yang and Xu, 2004). Additionally, overpressures and decreased porosity in the Palaeogene formations (depth $\geqslant 2000 \mathrm{~m}$ ) (see Figs. S1 and S2) are likely caused by sediments compaction. Groundwater in the Paleogene sediments is characterized with high TDS mostly higher than $10 \mathrm{~g} / \mathrm{L}$ (Sun et al., 1982), which should be distinct in origin from the Neogene (and Quaternary) groundwater. In sum, the active groundwater flow system may extend much deeper beyond the Quaternary aquifer bottom into the upper Neogene sediments and compaction-driven flow may be still present in the deeper parts of the basin. This has generally not been considered in previous conceptualizations of flow regime in the $\mathrm{NCB}$, which have assumed an impermeable base below the Quaternary aquifers (Fig. 4). 
A

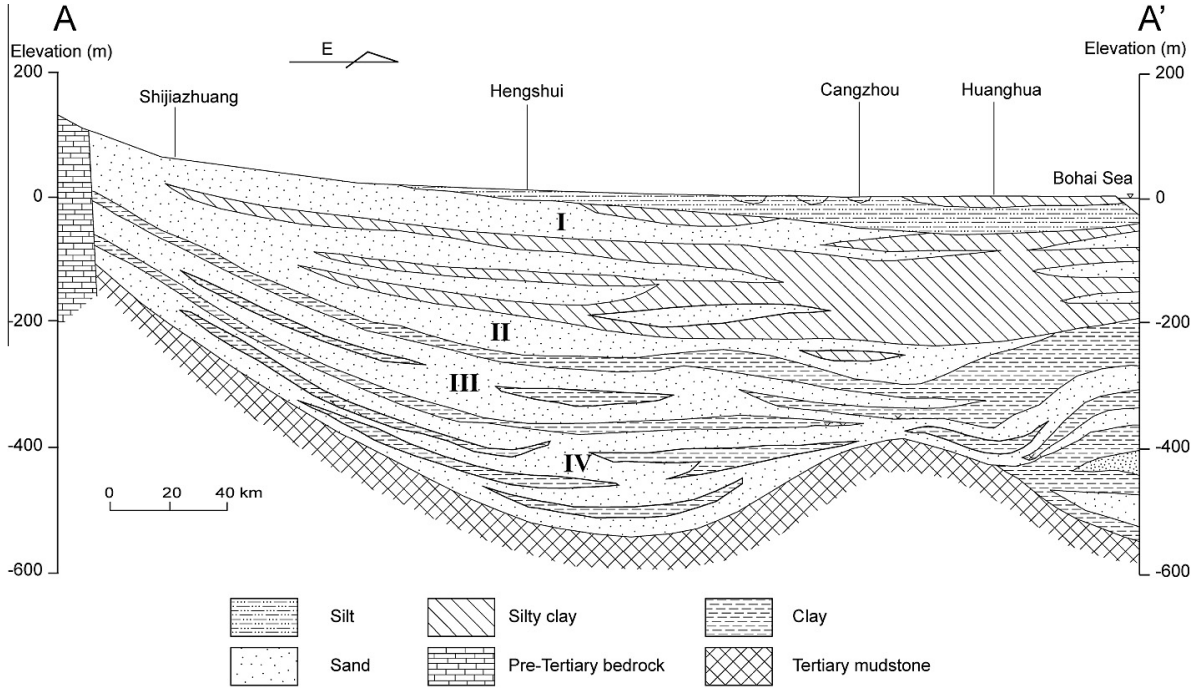

Fig. 3. Conceptual cross section showing the Quaternary aquifer units along the A- $\mathrm{A}^{\prime}$ line shown in Fig. 1 (from Zhang and Payne, 1987).

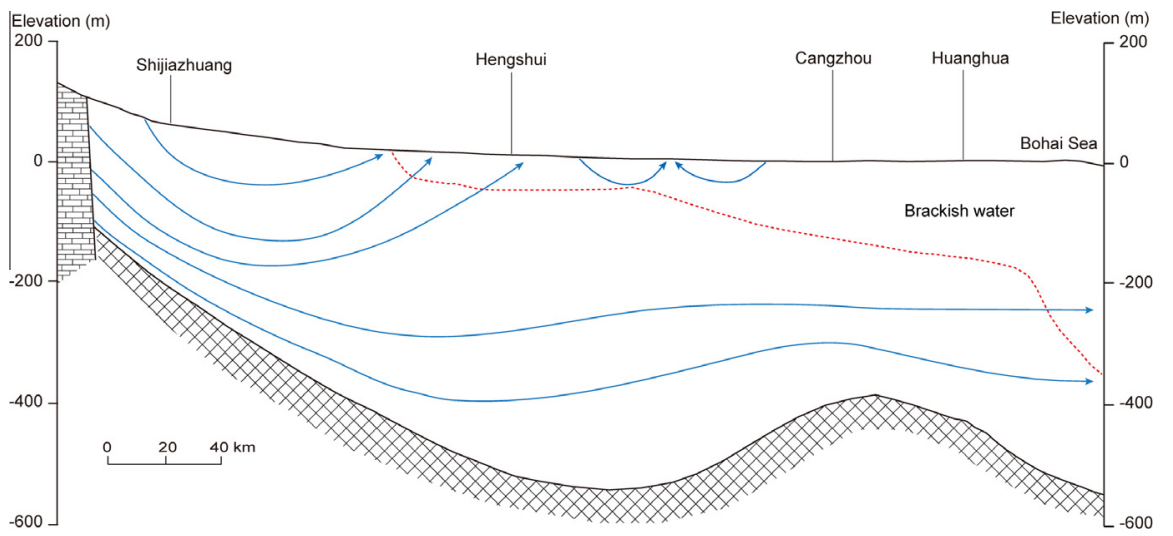

Fig. 4. Conceptual model for groundwater flow in the NCP (modified after Zhang and Payne, 1987; Zhang et al., 1997, 2000).

\subsection{Isotopic and groundwater age data}

The stable isotope compositions of groundwater show that all samples from Quaternary aquifers and most samples from Neogene aquifers in the Jizhong Depression are distributed along the Global Meteoric Water Line (GMWL) suggesting the same meteoric water source, while groundwater samples from Eocene and deeper sediment layers have higher $\delta \mathrm{D}$ values and show an obvious ${ }^{18} \mathrm{O}$ shift (Fig. 5a) related to a relatively closed, warm, reducing environment. Groundwater samples from deep geothermal fields in the Cangxian uplift region have a narrow $\delta \mathrm{D}$ range and apparent ${ }^{18} \mathrm{O}$ shift (Fig. 5b) suggesting meteoric origin and long residence times allowing significant water-rock interactions. Similar geochemical and stable isotopic characteristic of the geothermal groundwater in the Neogene aquifers with low temperature groundwater in the overlying Quaternary aquifers (and precipitation) indicate a meteoric source of the geothermal water (Chen, 1988; Zhou et al., 2009). In contrast, stable isotopic data of the cold and shallow geothermal groundwater do not show ${ }^{18} \mathrm{O}$ shift. Offset of ${ }^{18} \mathrm{O}$ in deep geothermal groundwater in the Cangxian uplift and Huanghua depression may be caused by isotope exchange with oxygen enriched carbonate bedrocks at the higher temperatures in this region (Minissale et al., 2008), may reflect the hydraulic isolation between the shallow cold and deep geothermal groundwater.
There is also great contrast in estimates of groundwater residence time in the basin using different isotopic tracers, particularly between groundwater ${ }^{14} \mathrm{C}$ and ${ }^{36} \mathrm{Cl}$ or ${ }^{4} \mathrm{He}$ ages in the deep confined aquifers under the central and coastal plain (Fig. 6). The contradictions between ages from different tracers is a common phenomenon in complex hydrogeological systems that are greatly affected by groundwater mixing and/or diffusive input (e.g., Lavastre et al., 2010). Similar with many regional aquifers in the world with high inertia, radiocarbon ages of groundwater in the NCB indicate a primary recharge period during the last glacial period (Fig. 6; Edmunds, 2007). The oldest ${ }^{14} \mathrm{C}$ age of groundwater in the deep Quaternary aquifer under the central and coastal plains is approximately 35,000 years, approaching the maximum limit of the ${ }^{14} \mathrm{C}$ dating method (Kreuzer et al., 2009). Geothermal water ${ }^{14} \mathrm{C}$ ages of $15,000-25,000$ years indicate the water likely originated during the same period (glacial period in the Late Pleistocene) as the overlying fresh groundwater in Quaternary aquifers (Zhang, 1990; Yao, 1995). No apparent difference is observed between ages of geothermal water in the upper Neogene aquifers and low temperature groundwater in the deep part of the Quaternary aquifers (Figs. 6b and c). Radiocarbon data of geothermal water in the Neogene aquifers were obtained in the 1990s. These samples taken in the traditional way with carbon precipitation from large containers may be prone to contamination issues (Aggarwal et al., 2014). Therefore, these ${ }^{14} \mathrm{C}$ data may prevent very 

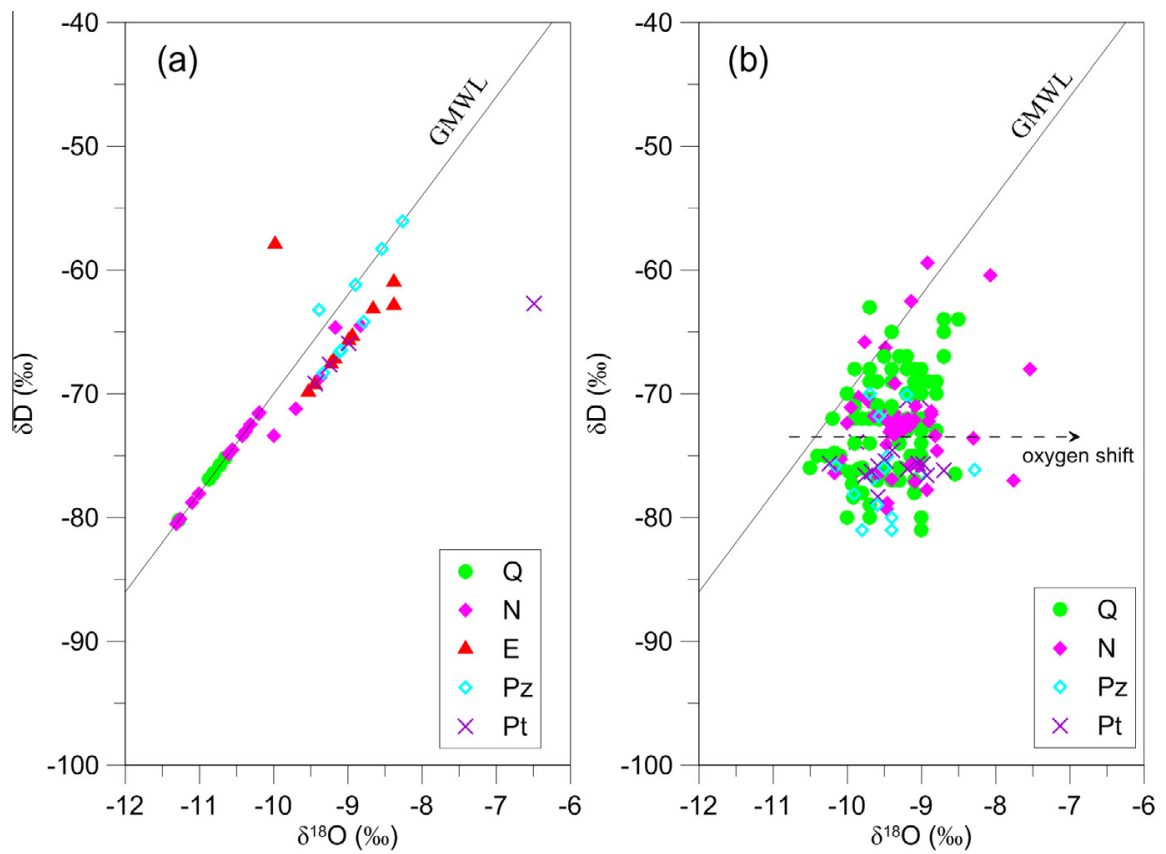

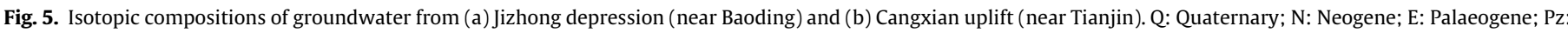

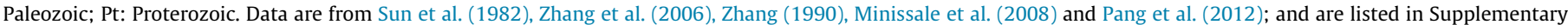
Table S1.
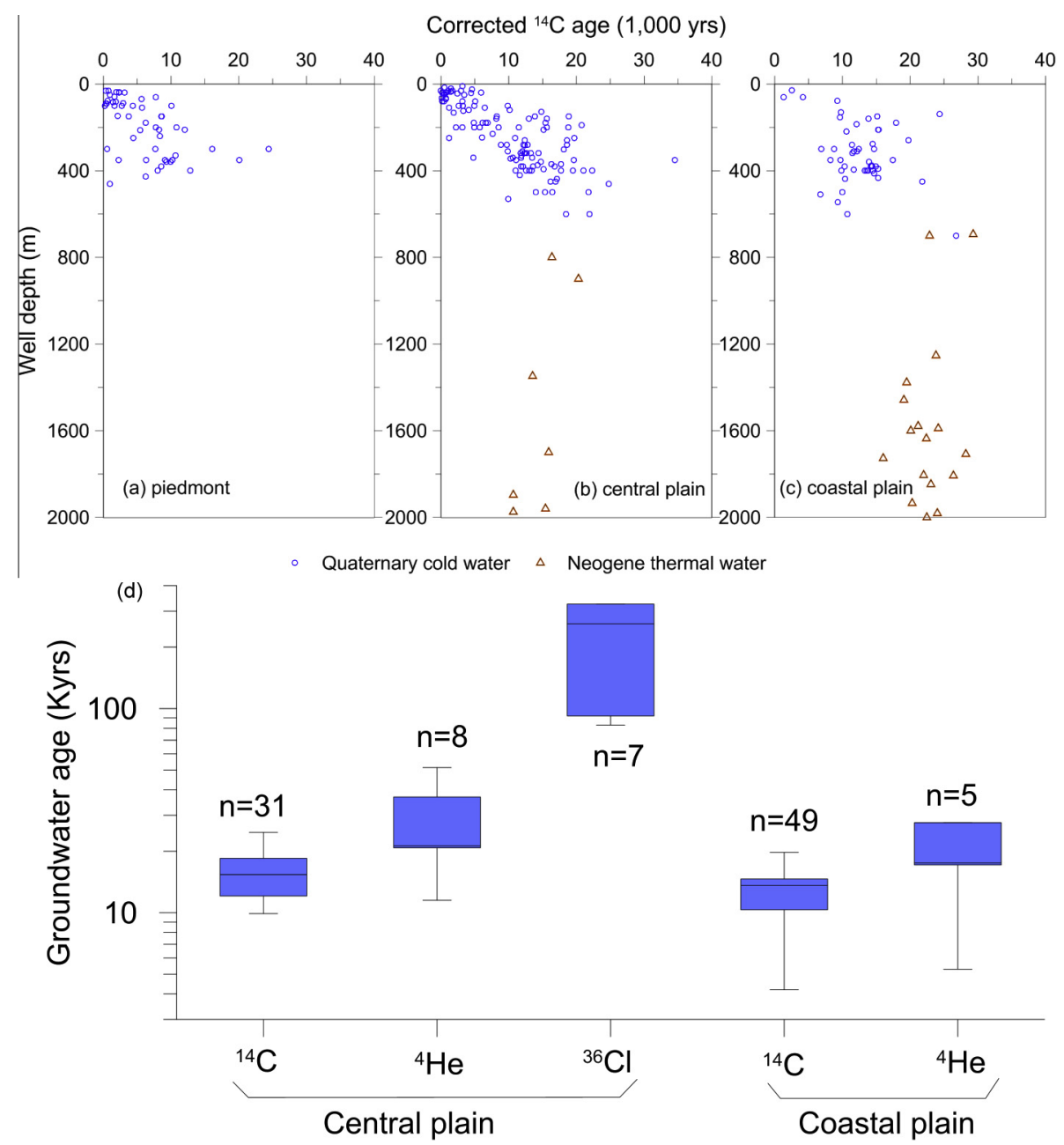

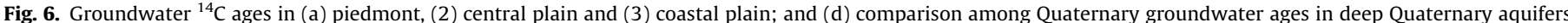

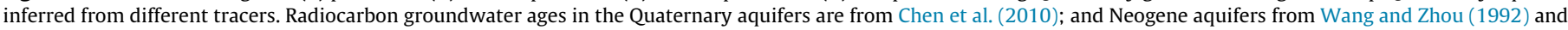
Yao (1995). Helium-4 groundwater ages are from Wei et al. (2015). Chloride-36 groundwater ages are from Dong et al. (2002). 
low activities (very old ages) to be properly measured (Kreuzer et al., 2009).

Groundwater age inferred from ${ }^{14} \mathrm{C}$ data in the NCB has mostly adopted sampling in production wells (with long well screens), showing increases from the piedmont region toward coast, and this pattern was used to validate the conceptual model of regional groundwater flow in many previous studies (Zhang and Payne, 1987; Zhang et al., 1997; Chen et al., 2005; Kreuzer et al., 2009). The depth of wells penetrated in the Quaternary aquifers are systematically increasing from the piedmont to the coastal plains because the depth of aquifers bearing usable groundwater increases toward the coast (von Rohden et al., 2010). The variations of groundwater age in the horizontal directions may be obtained by comparing those samples taken from the same depth, which show that the increasing trend toward the coast may not be quite obvious (Fig. 6). The vertical age structure may be more clear than the in the horizontal directions; and a general trend of increasing groundwater ages with well depth exists throughout the basin (Fig. 6). The measured groundwater ages may reflect long travel time along vertical flow path rather than long horizontal travel distance across the basin. Therefore, the original conceptual model that groundwater ages along flow path both in horizontal and vertical direction may not be reasonable supported by the measured groundwater ages. The age difference between groundwater in Neogene aquifers in the Jizhong depression and Quaternary aquifers under the piedmont recharge region may suggest an approximately 10,000-year timescale for infiltrated glacial meteoric water to penetrate the Pleistocene aquifers to the Neogene aquifers.

Groundwater ${ }^{36} \mathrm{Cl}$ ages have been proposed to be as old as hundreds of thousands years in the Jizhong depression (Liu et al., 1993; Dong et al., 2002), however, these age estimates are still subject to considerable uncertainty, particularly regarding the assumptions around initial ${ }^{36} \mathrm{Cl}$ activity. Evolution of meteoric water toward water characterized by high $\mathrm{Cl}$ content and low ${ }^{36} \mathrm{Cl} / \mathrm{Cl}$ ratio could be due to mixing with groundwater from deeper Neogene geothermal waters, through upward flow and/or release of $\mathrm{Cl}$ from pore water in compacted clay layers (Li et al., 2012). Helium-4 contents were also recently sampled in the deep Quaternary aquifers and showed comparable age ranges with ${ }^{14} \mathrm{C}$ ages in the piedmont region (Zhang et al., 2005; Sun et al., 2006; Kreuzer et al., 2009;

Table 1

Governing equations for steady-state groundwater flow, age and heat transport.

\begin{tabular}{lr}
\hline Conservation of water mass in steady state & \\
$\nabla \cdot(K \nabla h)+q_{s}=0$ & $1(\mathrm{a})$ \\
Conservation of thermal energy & \\
{$\left[\theta \rho_{w} c_{w}+(1-\theta) \rho_{s} c_{s}\right] \partial T / \partial t=\nabla \cdot(\lambda \nabla T)-\rho_{w} c_{w} q \nabla T-q_{s} T_{s}$} & $1(\mathrm{~b})$ \\
Conservation of solute mass & \\
$\partial C / \partial t=\nabla \cdot(D \nabla C)-\nabla \cdot(q C / \theta)+R$ & $1(\mathrm{c})$
\end{tabular}

Where $h$ is hydraulic head; $K$ is hydraulic conductivity tensor; $q_{s}$ is a volumetric flux per unit volume representing sink/source terms of flow; $q$ is Darcy flux; $\theta$ is porosity; $T$ is temperature; $\rho_{w, s}$ is water and solid density, respectively; $c_{w, s}$ is specific heat capacity of the water and solid, respectively; $\lambda$ is thermal conductivity tensor; $T_{s}$ is source temperature; $C$ is groundwater age; $D$ is hydrodynamic dispersion tensor; $R$ is source term for groundwater age, and is equal to 1 (the rate of aging of water) (Goode, 1996).
Wei et al., 2015). However, none of these studies illustrated any expected linear or non-linear increase in ${ }^{4} \mathrm{He}$ ages with the inferred flow direction across the basin from west to east. Moreover, higher ${ }^{4} \mathrm{He}$ concentrations occur in regions of uplifted basement (Cangxian uplift), indicating that a mantle source of ${ }^{4} \mathrm{He}$ should be an important input.

\section{Numerical simulation of groundwater age distribution and heat transport}

Groundwater age distribution in the NCB aquifers was simulated to estimate the time scale needed for the groundwater system to transition from steady state in the Late Pleistocene to a new steady state under modern present-day hydraulic conditions before significant groundwater extraction began. The groundwater flow model which simulated transient groundwater flow in the Quaternary aquifers for the past decades (1960-2008) and was calibrated with respect to hydraulic head observations (Cao et al., 2013b) was modified for groundwater age and heat simulations. The original finite difference grid bottom was extended $1000 \mathrm{~m}$ deeper to include the upper Neogene aquifers into the model domain, and the coastal boundary was extended several to hundreds of kilometers offshore, with a no-flow boundary of the easternmost model edge (see Fig. S3). Major perennial rivers were included in the model, but those rivers that had dried up were not. Groundwater age was simulated following the method derived by Goode (1996) with a mass conservation approach. The groundwater mean age, integrating the effects of dispersion, diffusion and mixing over the length of flow paths, may be a more sound approach to determine the spatial distribution of ages than the use of advective ages or point measurements of tracer-age, where the implicit assumption of piston flow is made (Cornaton and Perrochet, 2006; Newman et al., 2010). Groundwater age distribution controlled by advection and dispersion was simulated using the MT3DMS program (Zheng and Wang, 1999; Zheng et al., 2012) in a steady-state mode. The same code can be used to simulate the heat transfer when effects of buoyancy and changes in viscosity are small (Hecht-Méndez et al., 2010). Governing equations for groundwater flow, heat and age transport are given in Table 1.

A uniform anisotropy ratio (the ratio of hydraulic conductivities in horizontal and vertical directions, $K_{\mathrm{h}} / K_{\mathrm{v}}$ ) of 10,000 was used in the previously constructed flow model (Cao et al., 2013b) after calibration and was used as the base case simulation. Two more scenarios of aquifer anisotropy of magnitude 1000 and 100,000 were also considered. Because transport simulations generally require fine enough grid sizes to incorporate dispersivity, which is scale dependent and usually poorly constrained (in comparison to other hydraulic parameters), incorporating realistic dispersivities into a regional model is generally impractical (Sanford, 2011). Thus longitudinal dispersivity $(1000 \mathrm{~m})$ was chosen according to values which are commonly used in regional transport modeling (e.g., Castro and Goblet, 2005; Sanford and Pope, 2010; Schwartz et al., 2010), and considering the grid size used in this study. Transverse dispersivity $\left(\alpha_{T}\right)$ was taken as one tenth of longitudinal dispersivity $\left(\alpha_{L}\right)$. Considering the relatively small thickness of model domain compared with the total basin thickness, a uniform effective porosity of $25 \%$ was used neglecting the decreasing trend with depth

Table 2

Hydrogeological parameters of sedimentary units in the base case simulation.

\begin{tabular}{|c|c|c|c|c|c|}
\hline Aquifer & Material type & Hydrologic conductivity (m/d) & Porosity & $K_{\mathrm{h}} / K_{\mathrm{v}}$ & Thermal conductivity $\left(\mathrm{Wm}^{-1} \mathrm{~K}\right)$ \\
\hline $\mathrm{Q}_{4}-\mathrm{Q}_{3}$ & Sandy soil & $3-200$ & 0.25 & 10,000 & 1.0 \\
\hline $\mathrm{Q}_{2}-\mathrm{Q}_{1}$ & Sandy soil & $5-60$ & 0.25 & 10,000 & 1.0 \\
\hline Neogene & Sandy rock & 1.8 & 0.25 & 10,000 & 1.5 \\
\hline
\end{tabular}


(see Fig. S1). Hydrogeologic parameters of sedimentary units under the base case simulation are given in Table 2 .

The top boundary was defined as specified hydraulic head boundary, set to the measured water table elevations in the land areas (see Fig. 1) and fluid pressure in the marine area (the Bohai Bay). This is commonly used in basin-scale groundwater flow and solute migration (e.g., Michael and Voss, 2009; Gupta et al., 2015). The predevelopment water tables (before extensive groundwater pumping from the confined aquifers) were derived from an early constructed water table map in 1959 using water level measurements from hundreds of wells (Fig. 1). The temperature was set to constant value of $15^{\circ} \mathrm{C}(288 \mathrm{~K})$ at the top boundary. Groundwater age is specified zero at the top boundary assuming only young groundwater entering into the aquifer and ignoring the delay due to unsaturated flow. For the boundary conditions, a no-flow boundary in the flow model becomes a no "age-mass" (the product of age of a groundwater sample and its mass, see Bethke and Johnson, 2002) boundary in the age transport model. An outflow boundary, on the other hand, is allowed to carry an advective (but not dispersive) "age-mass" freely out of the model domain. A uniform heat flux of $54.4 \mathrm{~mW} \mathrm{~m}^{-2}$ was applied at the lower boundary based on the mean value of distributed heat flux in the basin (Chen, 1988).

\section{Results and discussions}

\subsection{Groundwater recharge, discharge and flux}

\subsubsection{Topographic hinge line and groundwater discharge}

As with most regional groundwater flow, groundwater table height variations caused by the (low) topographic relief are expected to be controlling groundwater flow patterns in the NCB. Compared to the alternating convex/concave slope profile investigated by Tóth (1963) and subsequent case studies (e.g., Gleeson and Manning, 2008; Goderniaux et al., 2013), the topographic gradient in the NCB is associated with a different depositional environment across the plains, showing a low-relief concave shape from the piedmont to central plain (see the embedded figure in Fig. 1a). The slope of piedmont of the Taihang Mountains ranges between $2 \%$ and $1 \%$, but the slope in the alluvial and coastal plains is less than $0.5 \%$ (Chen and Xu, 1986). These variations in topographic gradient result in a break-in-slope line (or hinge line) (see the embedded figure in Fig. 1a) generally along the edges of dilluvial fans/alluvial plains, trending approximately southwestnortheast. This kind of topographic configuration is common for coastal alluvial-dilluvial plains with sediment sources derived from adjacent mountains. This concave slope and upward break-in-slope of the water table generally results in upwards components of groundwater flow beneath the area of lower slope, and the emergence of a wide discharge zone (Freeze and Witherspoon, 1967; Duffy and Al-Hassan, 1988; Forster and Smith, 1988; Winter, 1999). Numerical studies (e.g., Duffy and Al-Hassan, 1988) demonstrated that under this topographic configuration, groundwater discharge is at a maximum just inside the hinge line, decreasing toward the lowest topographic discharge point (in this case, Bohai Bay).

The steady-state flux simulated across the upper boundary of the model shows a narrow zone of high groundwater discharge $(100-200 \mathrm{~mm} / \mathrm{yr})$ in the vicinity of the hinge line, and a broad, low discharge ( $\leqslant 50 \mathrm{~mm} / \mathrm{yr}$ ) area in the central and coastal plains (Fig. 7). The discharge area of $\geqslant 50 \mathrm{~mm} / \mathrm{yr}$ in the vicinity of the break-in-slope accounts for about $86 \%$ of total discharge on land. All of the largest paleo-lake groups in the NCP were historically located along the edges of dilluvial fans in this break of slope area. The broad discharge area thus represents a region where groundwater leaves the aquifer system by means of small streams and lakes (which are not explicitly simulated in this study) and evapotranspiration. It is noteworthy that this broad diffuse discharge area emerging from our simulations is largely coincident with the area that had been suffering severe soil salinization before extensive agricultural development and land modification took place in the 1960s. There are numerous minor topographic lows across the NCP, and generally, high soil salt contents in these regions suggest that these depressions are also local groundwater discharge zones (Xia, 1984). As the model top boundary is assigned the groundwater table from a contour map developed from regionally scattered measurements, groundwater discharge in these localized regions cannot be fully examined. This issue deserves further attention, using more detailed local information to construct water table configurations at higher spatial resolution.

The pattern of discharge zones (Fig. 7) is also associated with changes in lithology and permeability-e.g., aquifer heterogeneity. Higher recharge in the piedmont region is associated with the higher permeability of the coarse aquifer materials and absence of continuous aquitards. Decreased flow velocity due to smaller permeability of finer deposits in the alluvial plains must results in water loss through uptake by evapotranspiration and upwards leakage to rivers. Both the high recharge and discharge zone found with the base-case model disappear on the simulated flux map at the upper boundary when uniform hydraulic conductivity is applied instead of the heterogeneous hydraulic conductivity $(K)$ field derived from geological evidence (see Fig. S4). This indicates that changes in lithology and permeability play important roles in controlling groundwater circulation.

Basin scale modeling indicates that groundwater flow is generally strongly influenced by hydraulic anisotropy imposed by discontinuous low permeability layers interbedded within the aquifer (e.g., Michael and Voss, 2009), which is typically difficult to constrain. As expected, lower anisotropy causes more localized flow cells, and higher anisotropy results in more regional flow. Larger vertical fluxes across a particular depth horizon with respect to lower anisotropy (Table 3) suggest flow paths should extend deeper than the higher anisotropy case. Comparable water flux across the Quaternary aquifer bottom with the amount of SGD suggests (see Table 3 ) that flow through the Neogene aquifers cannot be neglected, although its rate is relatively small.

\subsubsection{Submarine groundwater discharge}

According to the generally assumed (prior to our study) conceptualization of groundwater flow in the NCB (Fig. 4), regional horizontal groundwater flow across the aquifer system would primarily leave the aquifer as submarine groundwater discharge (SGD) to Bohai Bay. Our model simulations indicate that the amount of SGD is in fact much smaller than that near the topographic hinge line or the regional diffuse discharge in the central and coastal plain through vertical upward flow. Simulated SGD only accounts for $\sim 2 \%$ of recharge, a relatively insignificant component of the regional groundwater budget (Table 3 ). The result is largely due to the low permeability of the aquifers at the eastern end of the basin, the fact that the sea water depth is relatively shallow in the Bohai Bay (average water depth of $\sim 12.5 \mathrm{~m}$ ), and the much smaller slope of the sea floor (e.g., relative to the slope in the Piedmont/central plain transition). This simulation result is in contrast with the significant amounts of SGD inferred by radium isotope mass-balance calculations (Wang et al., 2015). This may be explained by under-estimation of the terrestrial sediment runoff entering the bay, which may serve as a significant additional secondary source of radon in the marine water of the bay. The depth to the bottom boundary of the saline water can extend to $1000 \mathrm{~m}$ along the coast line (Chen and Xu, 1986); and this also 


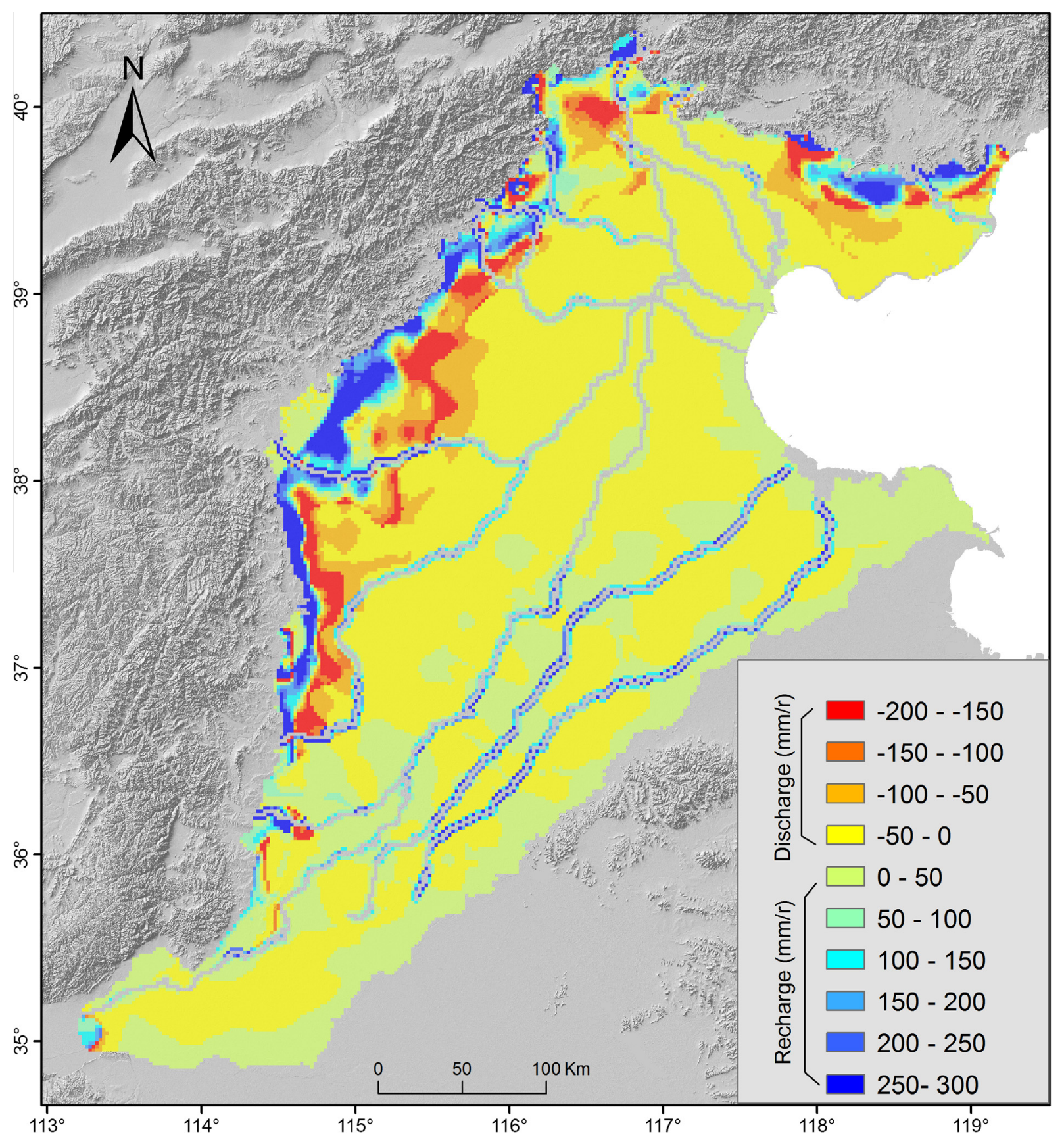

Fig. 7. Steady state distribution of flux (recharge-discharge) across the upper boundary. Linear features are rivers.

suggests that the amount of SGD from regional flow in the freshwater Quaternary aquifers is limited.

\subsection{Groundwater age and hydrodynamic stagnant groundwater}

In the previous section, we examined how the topographic relief and basin-scale aquifer heterogeneity controls the regional groundwater flow patterns. However, the picture of groundwater flow is not necessarily illustrated entirely by steady-state flowpaths under the current day topography and modern water table configuration. As totally impermeable sediments do not exist, the pattern of a flow field depends on the timescale examined (Tóth, 2009). In other words, the time needed for a flow system to convert from an equilibrium to a new near-steady-state condition is a crucial factor when evaluating groundwater flow systems (Rousseau-Gueutin et al., 2013; Currell et al., 2016).

\subsubsection{Groundwater flowpaths and velocity}

Simulated flowpaths using base-case anisotropy $\left(K_{\mathrm{h}} / K_{\mathrm{v}}=10,000\right)$ illustrate regional flow paths starting at the piedmont region, with advective travel times of mostly $\geqslant 200 \mathrm{Kyrs}$ (Fig. 8). Overlapping shorter and longer flowpaths between the mountain front and the central plain indicate multiple scale groundwater flow systems in this region. The pathlines with travel times of $\leqslant 50$ Kyrs approximately coincide with the area covering the recharge zone to the primary discharge zone in the vicinity of the topographic hinge line. Shorter distance flow paths with large travel times in the central and coastal plain suggest that the 
Table 3

Groundwater fluxes for different scenarios. Recharge rates are averaged value over the land area. Flux rates (SGD and flux across different depth) are presented as percentage of recharge rates). Flux100, FluxQBot are flux rates at $100 \mathrm{~m}$ depth and Quaternary aquifer bottom, respectively.

\begin{tabular}{lrllrl}
\hline Scenarios & $K_{\mathrm{h}} / K_{\mathrm{v}}$ & $\begin{array}{l}\text { Recharge } \\
(\mathrm{mm} / \mathrm{yr})\end{array}$ & SGD & Flux100 & FluxQBot \\
\hline Low anisotropy & 1000 & 57 & 2 & 22 & 2 \\
Base case & 10,000 & 32 & 2 & 11 & 1 \\
High anisotropy & 100,000 & 19 & 1 & 3 & 0 \\
Low sea level $(-10 \mathrm{~m})$ & 10,000 & 33 & 6 & 11 & 1 \\
Uniform K & 10,000 & 14 & 4 & 8 & 2 \\
\hline
\end{tabular}

secondary topography (topographic depressions, high stage river channels) may result in some relatively local groundwater flow, but generally more stagnant conditions. Those local flow systems were however not examined in detail, due to the coarse resolution of water table distributions available. The local topographic gradient in these minor lows in the plain can be as high as 5\% - ten times higher than the regional gradient, and therefore theoretically these should capture flow from a certain depth within a steady-state flow regime. This highlights the importance of three dimensional simulation of flow paths for complex topographic configurations.

Groundwater flow velocities also clearly show that flow in the piedmont region and the west of the Cangxian uplift is the primary active groundwater flow system carrying most of the flux (Fig. 9). Much of the recharged groundwater in the piedmont region moves laterally to a depth generally shallower than $500 \mathrm{~m}$. Relatively fast travel times in this region are attributed to the high flow velocity of $\geqslant 4.0 \mathrm{~m} / \mathrm{yr}$ (specific discharge/porosity). With lithology changing to finer deposits and permeability decreasing to the east, groundwater velocity decreases dramatically; and groundwater is

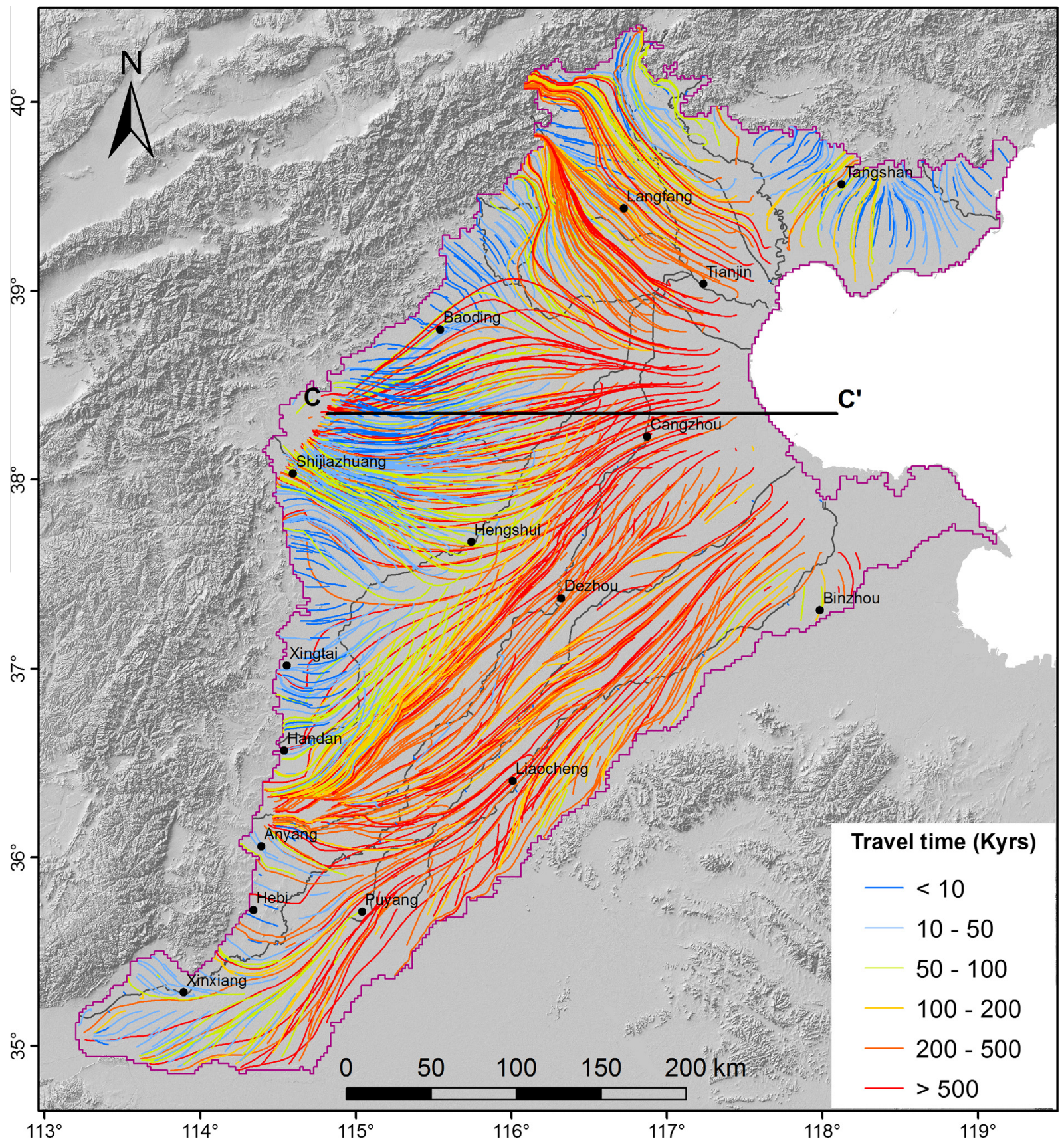

Fig. 8. Groundwater advective flow paths coded by travel time. Flow paths were obtained by backward tracking particles placed at the water table 10 km apart. 

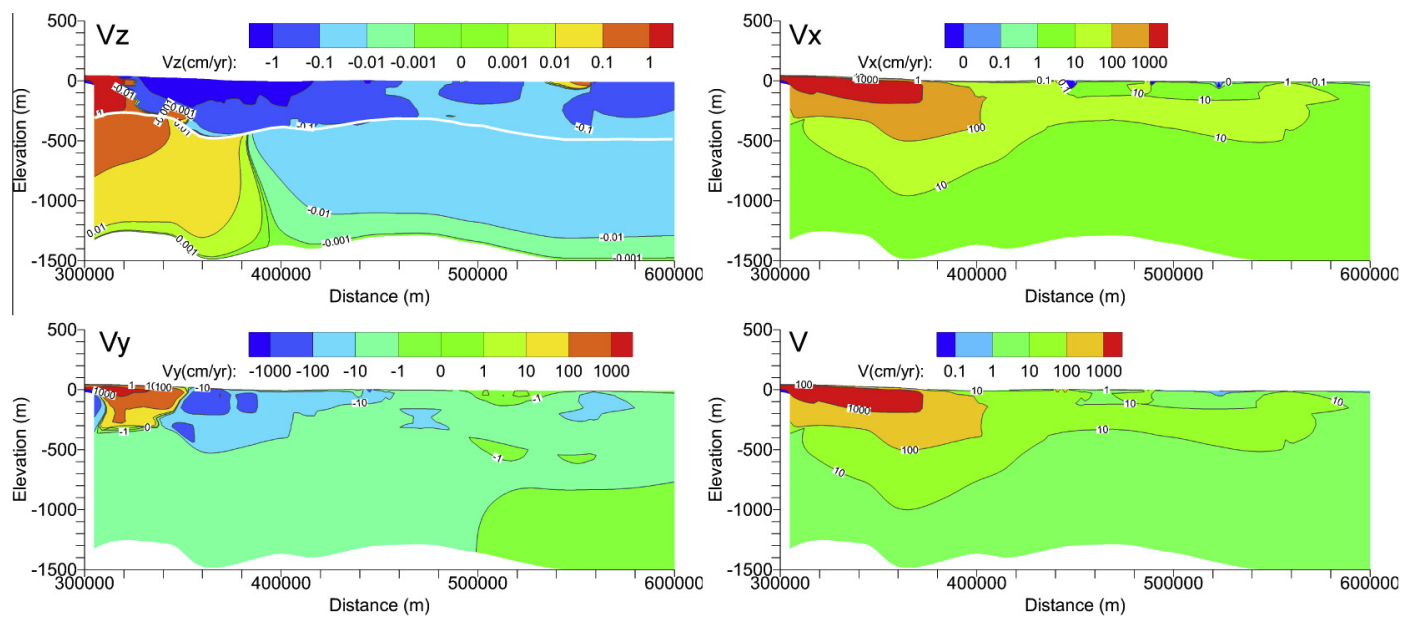

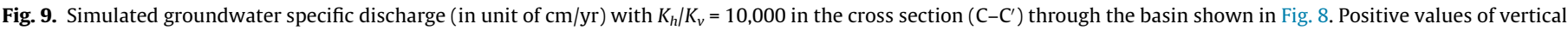

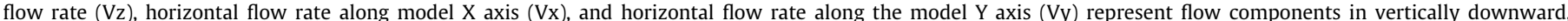

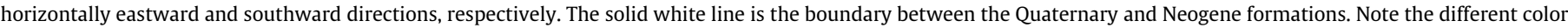
scales for different directions.

discharged through weak upward vertical flow to the ground surface. The abrupt changes in stable isotropic compositions (Fig. 5) at the boundary confirm that the through flow from the Jizhong depression to the Cangxian uplift and Huanghua depression is limited. In aquifers deeper than $500 \mathrm{~m}$ under the central and coastal plains, groundwater velocity is generally less than $0.4 \mathrm{~m} / \mathrm{yr}$, in consequence, the flux in deep parts of the aquifer (depth $\geqslant 500 \mathrm{~m}$ ) is reduced significantly (Table 3 ), suggesting groundwater in this section has restricted drainage/outflow.

The variations in groundwater velocity can also help explain the groundwater isotopic age distribution pattern. Low horizontal velocity under the central and coastal plain results in horizontal movement of only several kilometers within the timeframe of the maximum radiocarbon age determination scale ( $\sim 30 \mathrm{Kyrs})$. The age differences between two points that are hundreds of kilometers apart must be complicated in addition by local recharge, vertical flow and extensive groundwater mixing along different paths in three dimensional space. Therefore, it is understandable that no apparent increasing trend in age with distance occurs in the central and coastal plains according to radiocarbon data. Moreover, it may be meaningless to make a comparison between advective ages and isotopic ages, when velocity is small (as piston flow does not apply). Therefore, groundwater age increasing with depth (see Fig. $6 \mathrm{a}-\mathrm{c}$ ) would be the expected dominant pattern in the entire basin-this is largely observed in the isotopic datasets. One aspect of the isotope data from the NCB which is of interest is the occurrence of relatively young groundwater ages (i.e., still containing measurable radiocarbon) within the deep, upper Neogene sediments in the Jizhong depression (Fig. 6b). In addition to the possible contamination issue in these earlier ${ }^{14} \mathrm{C}$ data collected in the traditional way (Kreuzer et al., 2009), a second explanation of this problem may be the relatively rapid vertical flow below the piedmont region or the deeper circulation from the mountains to the Neogene aquifers.

\subsubsection{Groundwater ages under modern hydraulic conditions}

The age pattern from the simulations clearly reflects features of the flow system before extensive exploitation. Groundwater is younger in the shallow aquifer units, increasing in age with depth (Fig. 10). Low aquifer anisotropy generally causes young groundwater bodies to extend deeper. Ages in the Quaternary aquifers in the Jizhong depression are generally $\leqslant 10 \mathrm{Kyrs}$, and are comparable with the ages inferred from radiocarbon. No significant difference is observed between the advective age and the simulated age in the Jizhong depression (see Fig. S5), suggesting that piston flow conditions are likely approximated in this section. Therefore, agreement between simulated ages and isotopic ages can be obtained in this region when appropriate hydraulic parameters are given (Fig. 11). However, part of the groundwater discharged at the central and coastal plain (i.e., beyond the regional discharge at the hinge-line) flows through the less permeable Neogene aquifer, resulting in rapidly increasing groundwater residence times. Groundwater age increases sharply between the Jizhong depression and Cangxian uplift, which is indicated by flowpaths and the vertical velocity distribution. Groundwater ages under the central and coastal plains east of the Cangxian uplift show an exponential flow pattern: young groundwater near the surface water table and age increasing with depth (Fig. 10). Simulated groundwater ages are much older than the radiocarbon derived groundwater ages for all anisotropy cases in the Huanghua and Jiyang depressions (Fig. 11). The advective ages become progressively older than the simulated ages in these depressions, and the advective ages reach up to $\sim 200$ Kyrs in the shallow parts of the Huanghua and Jiyang depressions (see Fig. S5). These age estimates are more comparable with ${ }^{36} \mathrm{Cl}$ and ${ }^{4} \mathrm{H}$ ages previously reported (Liu et al., 1993; Dong et al., 2002; Wei et al., 2015).

Simulated maximum groundwater ages in the deepest part of the aquifers are approximately 1 Myrs (Fig. 10), comparable with the depositional timescale of the Pleistocene sedimentary deposits. Because of difficulty constraining effective porosity, groundwater mixing and the role of diffusion or flow from low permeability layers (e.g., Bethke and Johnson, 2008; Sanford, 2011); it is challenging to use model simulated ages to depict the real groundwater age distributions (e.g., Aeschbach-Hertig, 2005). Nevertheless, the very high residence times in these areas of the central and coastal plains suggests that the deepest groundwater may have been preserved since formation in the Pleistocene, and has not been totally flushed out by subsequently entering water. Upward vertical flow of these deep waters and mixing with shallow younger groundwater may cause significantly older ages in the shallow aquifers.

The contrast among groundwater ages derived using different environmental tracers may be attributed to the different time scales applicable for various tracers and the complex mixtures of water represented by a sample (McCallum et al., 2015). The difference between tracer-based and simulated groundwater ages suggest that the groundwater flow system never reverted to an equilibrium condition determined by the current topography and modern hydraulic conditions. The impact of modern-day intensive 

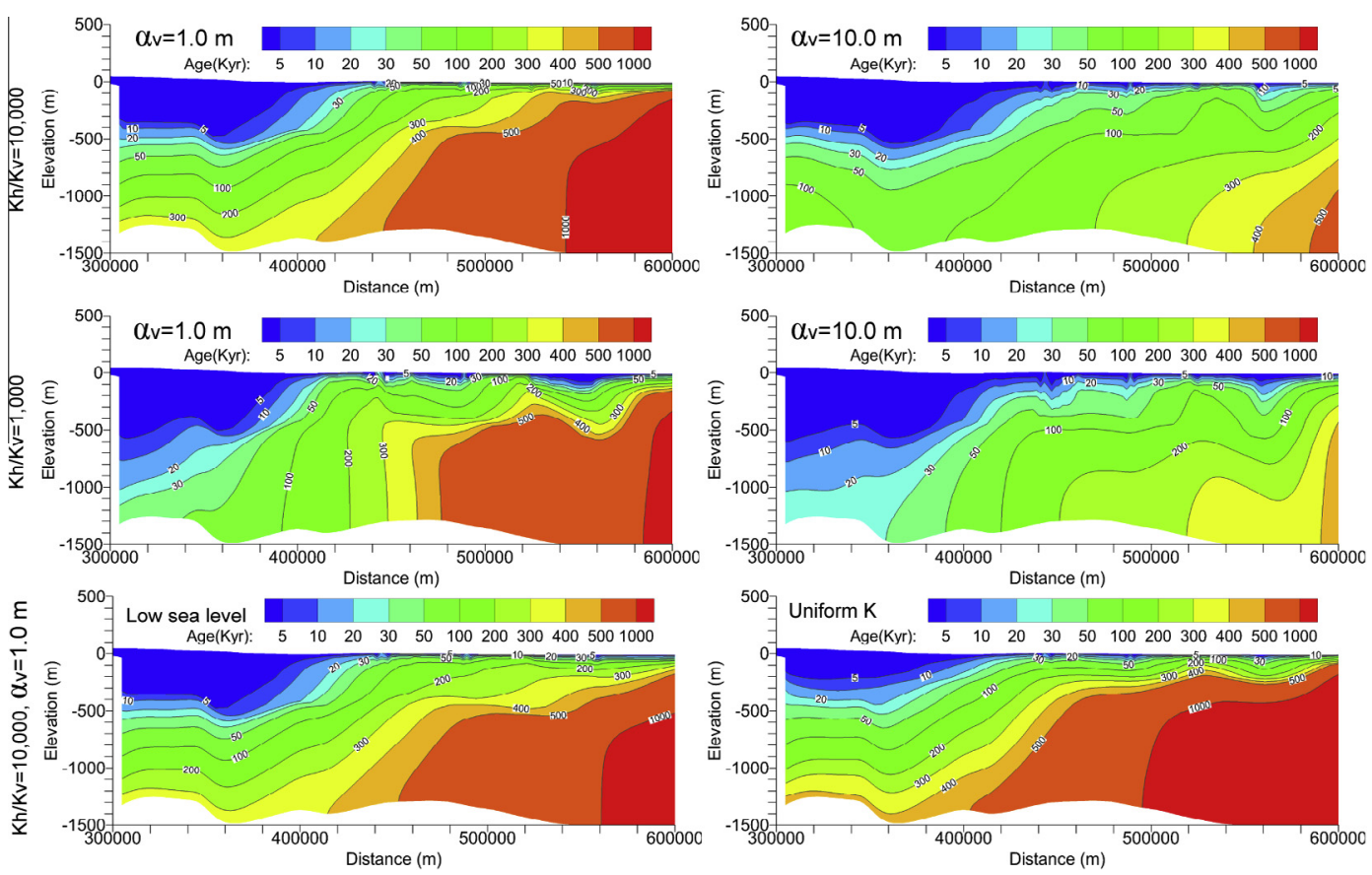

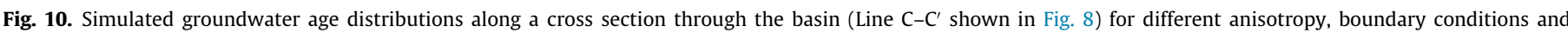
different scale dispersion effects.

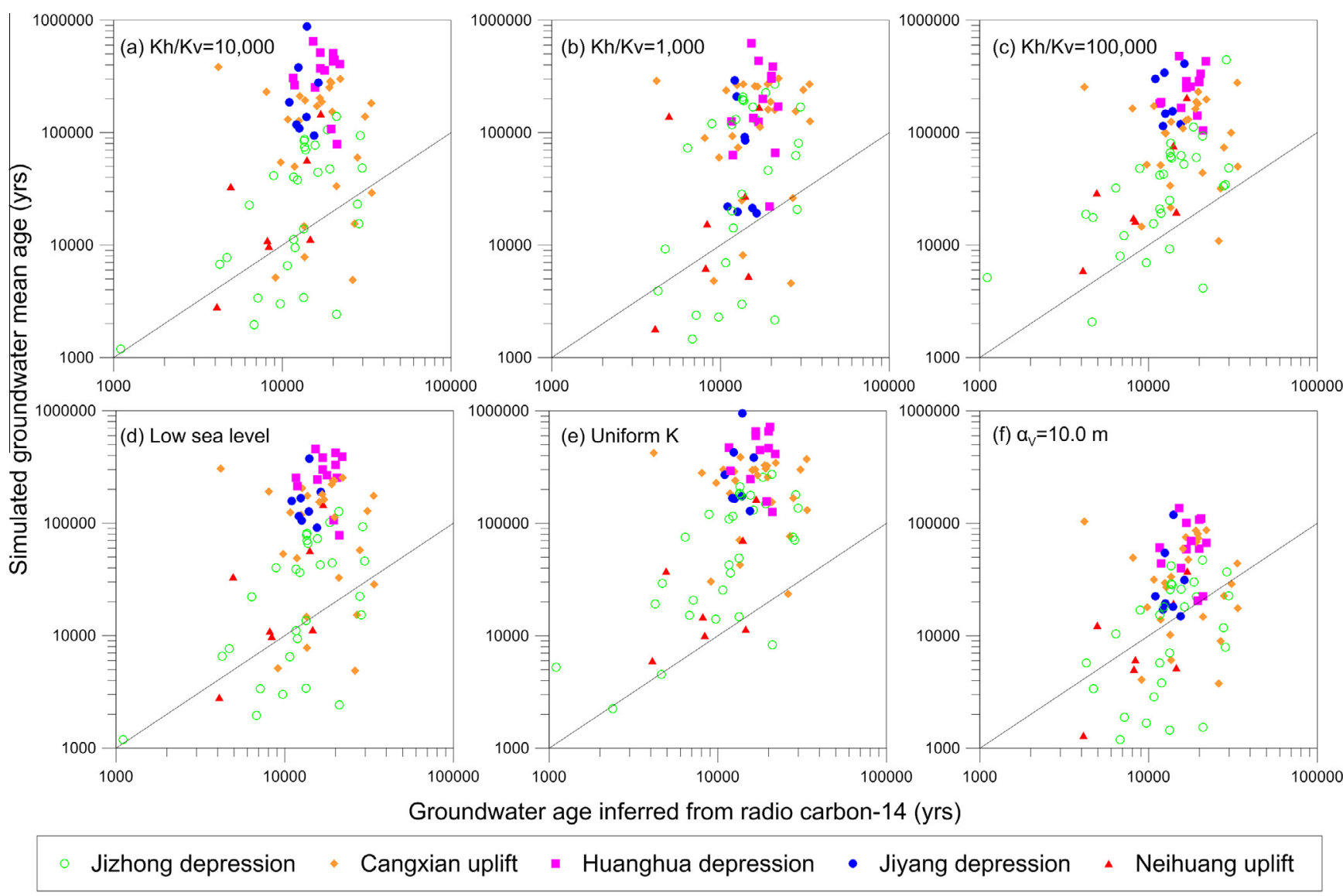

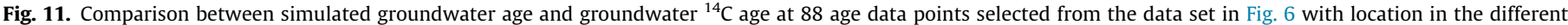

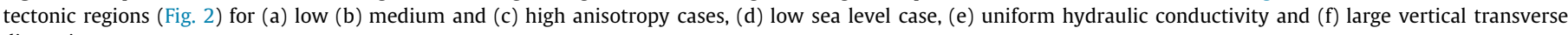
dispersion cases. 
groundwater abstraction on the flow regime is obviously a significant complicating factor in the interpretation of the tracer data. The time to reach near-equilibrium for the confined aquifers in the NCB predicted using these simulations is up to $\sim 1$ Myrs, suggesting that the aquifers are still far from steady state (RousseauGueutin et al., 2013). Deep groundwater under the central and coastal plains would appear to have limited replenishment capacity from flow originating in the piedmont area under our conceptual model-in contrast to the previous conceptual model. This underscores further that the intensive exploitation of deep confined aquifers in the basin (Cao et al., 2013b) is undoubtedly highly unsustainable.

The great difference in stable isotopic composition and groundwater ages between deep groundwater in the Jizhong depression and the rest of the NCB suggests that the hydraulic connection between these two sections may be restricted. Hydraulic continuity on regional scale (Tóth, 1995) implies that connection between different regions for basin scale groundwater flow depends on the specified time scale. The maximum simulated groundwater age $\left(10^{6}\right.$ years) suggests that deep groundwater may be stagnant, however, the absence of a regionally continuous thick aquitard suggests it is not reliable to think of the deep groundwater as totally isolated on timescales of interest. However, it can be proposed on the basis of our simulations that on a time scale of $10^{4}$ years or smaller, parts of the groundwater system-e.g., the 'stagnant zone' below the deep central and coastal plains-are affected by groundwater entering the piedmont area only to a very minimal degree. This region should be viewed as being only partially connected with the active groundwater system generated under the topographic/hydraulic conditions. The interface between the active groundwater system and the "stagnant groundwater" zone is most likely a widely spread transition zone, caused by long-term transient behavior and/or mixing due to hydrodynamic dispersion.

The base case simulation using a longitudinal dispersivity of $1000 \mathrm{~m}$, a horizontally transverse dispersivity of $100 \mathrm{~m}$ and a vertically transverse dispersivity of $1 \mathrm{~m}$ generates a maximum age of approximately 1 Myrs in the deepest aquifers. Increasing the longitudinal and horizontally transverse dispersivities has little effect on groundwater age (see Figs. S6 and S7), however, including larger vertical dispersion in the model leads to much younger ages (Figs. 10 and 11), consistent with the observations described in Engesgaard and Molson (1998) and Bethke and Johnson (2008). There is a strong possibility that groundwater ages in the thick inter-layered aquifer are affected by a strong degree of vertical mixing and dispersion (including a component of diffusion from neighbouring low-permeability layers), and more information is necessary to evaluate dispersivity values.

The groundwater recharge and discharge zones in steady-state flow are independent regions. However, this may be complicated in plain areas with relatively little topographic variation considering the dynamic hydrological conditions controlled by climate. The recharge and discharge (mainly through evapotranspiration) zones may in fact coincide, with seasonal alternation. Although piedmont regions are the primary regions receiving most groundwater recharge, no evidence could be shown that the central plains and coastal plains are net discharge zones in an annual climatic cycle. Therefore, neglecting groundwater flow in possible sub-basins associated with minor topography lows and enhanced flow extending depth by dynamic top boundary conditions might overestimate groundwater ages to a specific depth, which also suggests that it is necessary to conduct transient flow simulations with water table configuration in high spatial resolution.

\subsubsection{Effects of coastal boundary on age distribution}

Underlying Tóth's (1963) studies is the fundamental assumption that the subsurface drainage boundary coincides with the surface drainage boundary at the largest scale. That is, no subsurface inflow or outflow is permitted at the model boundary, forcing all recharge to emerge as river flow at the lowest basin outlet. However, this may not be the case in a real world setting (e.g., Sanford and Buapeng, 1996). A transient flow simulation reproducing the changing extent of the flow system boundaries from past to present may also be desirable, for regional systems subject to changing boundary conditions over geologic timescales. This can be simulated to illustrate the impacts of such changes to the flow field (Lemieux and Sudicky, 2010; Schwartz et al., 2010). In practical application, however, because no actual recharge and flow data for the geologic past is available, a steady-state flow field which is simulated under current recharge conditions is commonly used assuming steady-state flow in the past.

Although it is generally thought that the world-wide sea level low stand during the Last Glacial Maximum (LGM) could result in faster groundwater velocity and enhanced recharge (e.g., Morrissey et al., 2010; Plummer et al., 2012), multitracer studies in the NCB suggest that LGM recharge is likely not present to a great degree, due to climatic effects, and a greater abundance of groundwater ${ }^{14} \mathrm{C}$ ages approaching the dating limit ( $35 \mathrm{Kyrs}$ ) suggests significant recharge prior to this time, during the past glacial period (Chen et al., 2005; Kreuzer et al., 2009). In the LGM, sea level was approximately $120 \mathrm{~m}$ lower than present, and the Yellow River extended its course across the Yellow Sea and discharged to into the Okinawa Trough (Ren and Shi, 1986; Wang, 1990). This means that the coast was at least $500 \mathrm{~km}$ east of the present coastline, causing the entire Bohai Bay to be exposed as part of the plain. Assuming the water table was highest in the piedmont plain as at present, simple calculation shows that the increase in the averaged hydraulic gradient between the piedmont and sea during the LGM was minimal, considering the increased longer flow distance to the paleo-shoreline. The slope of the submarine topography in the Bohai Sea is approximately 0.2\%o (Cao et al., 2013a, see the embedded figure in Fig. 1a), which would result in only a small regional increase in the horizontal hydraulic gradient in the LGM. Moreover, no incised valley morphology is detected in the Yellow River Delta area to suggest marked paleo-topography development during the LGM (Zhou et al., 2014). Therefore, whether groundwater velocity was enhanced in the LGM is questionable; and the possibility of regional groundwater flow system under the LGM hydraulic conditions (Zhang et al., 2013) deserves further investigation. The existence of old residual groundwater far prior to this time is thus a possibility.

In our simulations we attempt to account for this by changing the sea level of the coast boundary and assessing the effect on flow patterns. The Bohai Bay would have been exposed for an extended period during the last glacial period, when significant recharge took place. Simulated ages in the scenario using a lower sea level in the Bohai Bay indeed results in younger groundwater occurring in the shallow parts of the aquifers near the coast, however, this did not dramatically decrease the maximum groundwater ages in the deeper parts of the basin (Figs. 10 and 11). This would be expected, as under the NCB, the flow regime and topography dictate that most discharge occurs in the vicinity of the break-inslope just beyond the piedmont (rather than at the coast) and therefore groundwater flow patterns are not affected to a large extent by the position of the easternmost impermeable boundary (Forster and Smith, 1988, see Fig. 7).

\subsection{Geothermal anomalies and correlation with groundwater flow patterns}

Geothermal anomalies in the NCB primarily correlate with the basement structures: the geothermal gradient is commonly higher in uplifts and sub-uplifts within depressions (e.g., Chen, 1988; 
Wang and Zhou, 1992). The significant effects of basement structures were not simulated in the heat transport model (uniform heat flux was used at the bottom boundary), therefore, it is hard to compare the simulated groundwater temperatures with the in-situ measured data. Nevertheless, any temperature anomaly which can be distinguished from the normal conduction controlled geothermal field should indicate perturbations by convection assuming no other sources of heat. Affected more markedly by (downward) vertical flow of low temperature meteoric water, the geothermal gradient in the primary recharge zone is obviously lower than in the central and coastal plains (Fig. 12). This is consistent with spatial patterns of the geothermal gradient presented by Chen and Deng (1990). Figure 13 shows the transition from convection- to conduction-dominated thermal regimes related to reduced velocity under the central and coastal plains. Groundwater temperatures are suppressed under the recharge area in the Jizhong depression, while isotherms are subparallel to the flat surface topography except in the deeper parts of the basin (Fig. 13). The downward flow in the recharge area reduces the conductive

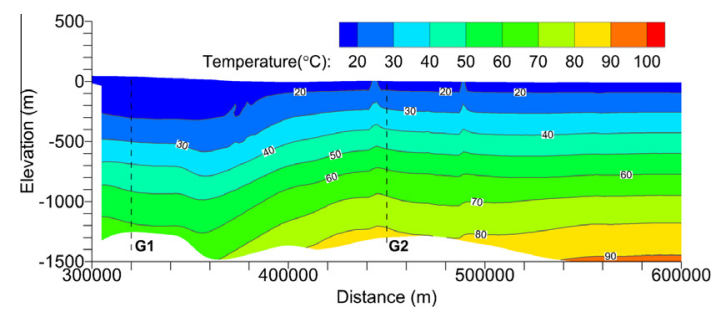

Fig. 13. Simulated groundwater temperature distribution (along the cross section $\mathrm{C}-\mathrm{C}^{\prime}$ shown in Fig. 8) using a uniform heat flow at the model bottom boundary.

geothermal gradient in the Quaternary aquifer, but results in a higher geothermal gradient in the upper part of the Neogene aquifer than in the lower part (Fig. 14).

Many previous geochemical investigations had suggested that the Quaternary and Neogene aquifers and the pre-Neogene are physically isolated without any mixing (e.g., Minissale et al., 2008). However, groundwater from some of the sampled wells in

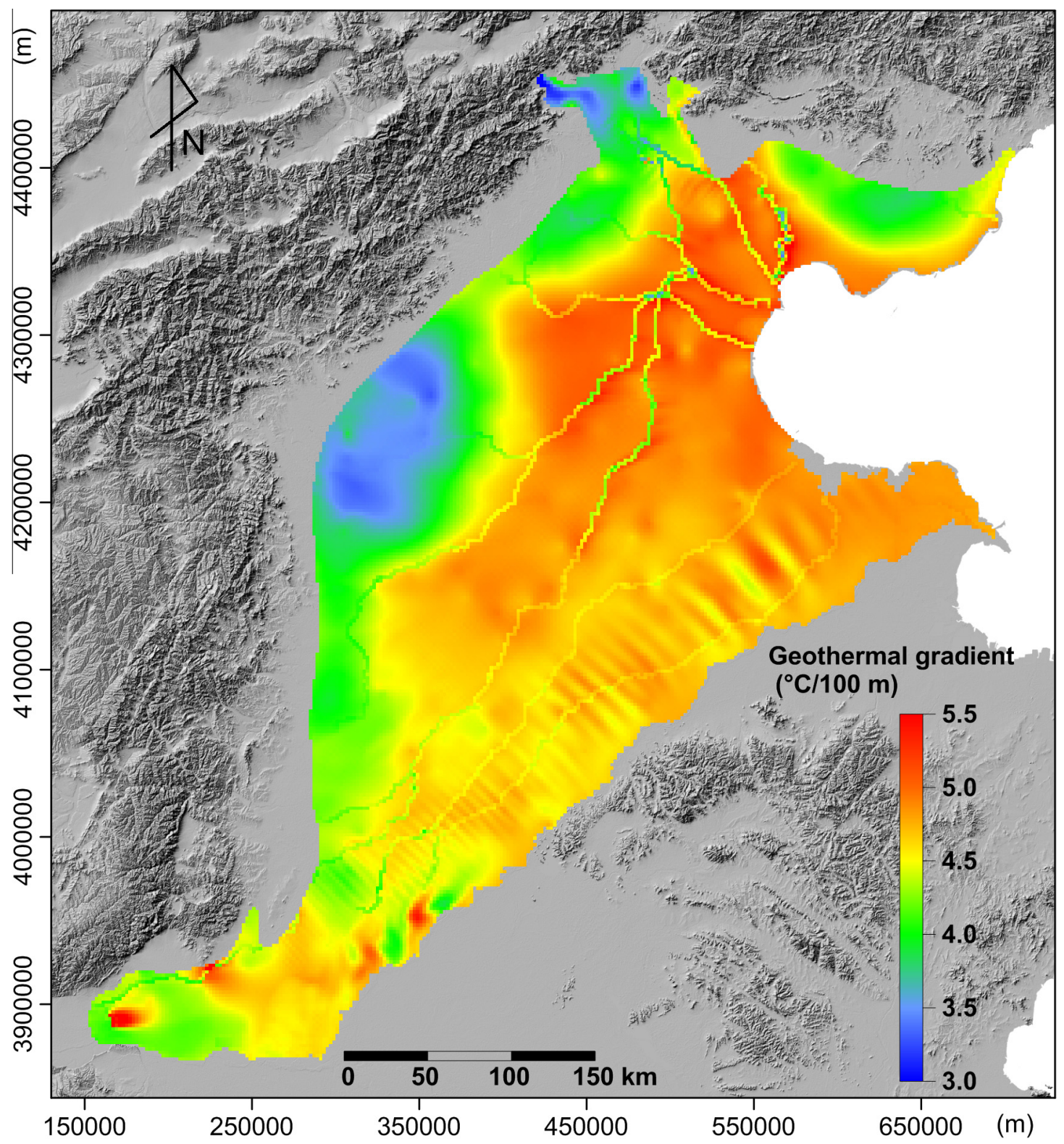

Fig. 12. Simulated averaged geothermal gradient in the Quaternary and Neogene aquifers. 

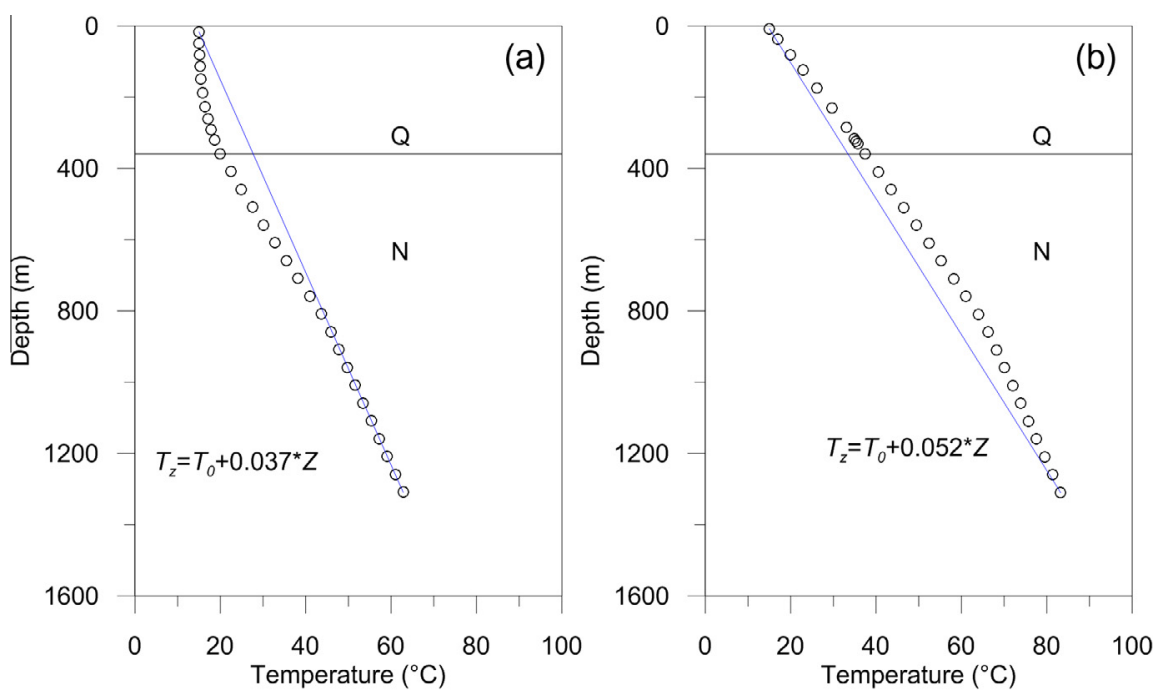

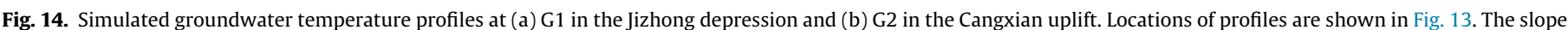

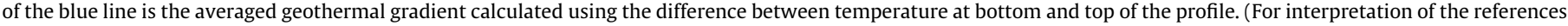
to color in this figure legend, the reader is referred to the web version of this article.)

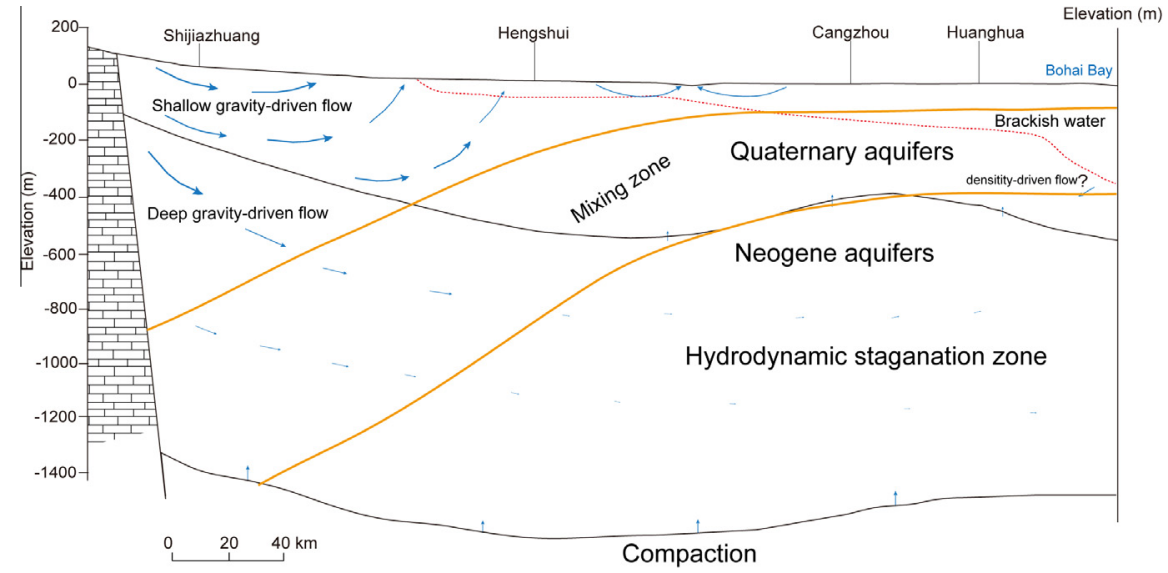

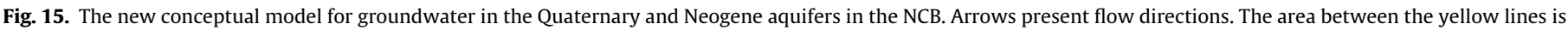

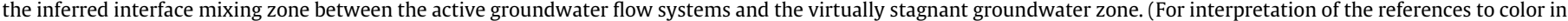
this figure legend, the reader is referred to the web version of this article.)

the deep Quaternary aquifers at the Cangxian uplift and Huanghua depression exhibit similar $\delta^{18} \mathrm{O}$ shift compared with the deep geothermal water (Fig. 5b). This indicates possible recharge from upwelling geothermal water along tectonic fractures. In the Jizhong depression, such upflow could be the discharge mechanism for groundwater in the depression area. In the Cangxian uplift and Huanghua depression, most geothermal water originates in the Yan Mountains and the upward flow in the Huanghua depression may be limited (e.g., Brandi et al., 1986). Upward flow from Neogene aquifers in the Jizhong and Huanghua depression, shown by the model simulations, temperature and geochemical datasets, indicate that groundwater flow in the NCB is not only controlled by water table configuration, but also the basement structure.

\subsection{New conceptual regional flow model}

According to previous isotopic data and the results derived from this study, a new conceptual model of regional groundwater flow patterns in the NCB is suggested, as is shown in Fig. 15. We propose that it is more reliable to consider the Quaternary and Neogene aquifers together when evaluating regional groundwater circulation, and more reasonable to view the deep groundwater in the NCB below the central and coastal plains as virtually stagnant, at least on human timescales (i.e., decades) or even longer on thousand-year timescales. Saturated groundwater beneath the terminal base of drainage (the sea) is generally thought more likely to be in "stagnant" state (e.g., Mazor, 2003); however, the possibly enhanced groundwater circulation depth under the central and coastal plains by local topography depressions can make the active groundwater flow infiltrate deeper beneath the sea level for the NCB case. The determination of the spatial distribution of the transition (mixing) zone between the active groundwater system (the primary groundwater system in Jizhong depression and local shallow groundwater systems in central and coastal plains) with the deep stagnant groundwater is a challenging topic for future research. Nevertheless, the vertical position of the interface can be partially constrained through chemical and isotopic compositions (e.g., Mazor, 2003). Differences in stable isotope compositions of Neognene groundwater in the Jizhong depression (Fig. 5a) suggest that the shallow part of the Neogene aquifers probably belong to the active groundwater flow system. Groundwater in the Quaternary aquifers under the central and coastal plains exhibits 
signals of mixing with deeper geothermal water (Fig. 5b), suggesting deeper parts of the Quaternary aquifers are the mixing zones under these regions. The top limit of the mixing zone depends on the groundwater circulation depth of the active groundwater system and is inferred to become shallower from the piedmont region to the central and coastal plains (Fig. 15). The width of the mixing zone in vertical direction would be a dynamic parameter associated with the active groundwater flow system showing dynamic response to climate change.

\section{Future study}

The evolution of groundwater salinity and impacts of saline water on groundwater flow were not considered in this study, due to complex origin and processes (Chen and Xu, 1986; Liu et al., 1987; Zhang and Payne, 1987; Li et al., 2012; Chen et al., 2014). The TDS concentration of the saline water can be up to $30 \mathrm{~g} / \mathrm{L}$. The saline water is generally located at depth $<60 \mathrm{~m}$, except in the coastal area where saline water occurs to a depth of $1000 \mathrm{~m}$ (Chen and Xu, 1986). Density-driven groundwater flow may drive saline groundwater to move a considerable distance in the opposite direction to the originally present fresh groundwater flow (e.g., Duffy and Al-Hassan, 1988; Delsman et al., 2014). Whether density-driven flow could play an important role in shaping the present groundwater salinity distribution could be evaluated by further paleo-hydrogeological modeling, to simulate the groundwater solute transport over a geologic timescale. Additionally, long-time scale salt transport in the basin can provide more information to evaluate dispersion which was not well constrained in the current study. The $\mathrm{Cl} / \mathrm{Br}$ ratios have been shown to be more sensitive to dispersivity than salinity or groundwater ages (Gupta et al., 2015), and including $\mathrm{Cl}$ and $\mathrm{Br}$ concentrations into salt transport modeling in the basin might help evaluate realistic dispersivity values. Multiple-layer sampling of saline groundwater and constructing vertical profiles of geochemical compositions and environmental tracer concentrations in the central and coastal plains could also improve understanding various salt originsincluding diffuse groundwater discharge as inferred in the simulations in this study.

\section{Conclusions}

We re-examined a range of isotopic tracer data and conducted new three dimensional groundwater age and heat transport simulations in the NCB, resulting in a substantially revised conceptualization of the flow system. The following conclusions can be made:

(1) An active groundwater flow system is generated between the recharge area in piedmont, and the primary discharge zone-in the vicinity of break-in-slope of the concave topography in the NCB. Neogene aquifers in the Jizhong depression are important components of this active groundwater flow system and the geothermal regime is significantly affected by strong downward flow. Including the Neogene sediments into the new conceptual model allows a greater role for deep groundwater circulation, particularly in the Jizhong depression.

(2) The groundwater system in the NCB has undergone different transient behaviors in different areas and on different timescales. We propose that the active groundwater flow system in the piedmont/central plain transition has always been present and that advective flow with maximum groundwater residence times in the tens of thousands years are dominant. In contrast, deep groundwater in the basin below the central and coastal plains is virtually stagnant on this timescale. A wide mixing interface zone between the active flow systems and stagnant groundwater might exist which can explain the controversy and discordance among groundwater ages derived from various tracers.

(3) Lower sea level in the LGM may result in higher groundwater velocity near the coast but this has limited effects in the piedmont region and central plain as most of groundwater discharge is in the vicinity of the break-in-slope. Groundwater entering the aquifer since the Pleistocene has not been totally flushed out in the deep parts of the basin, and the groundwater system is still in a process of conversion to a quasi-equilibrium state.

\section{Acknowledgements}

This work was supported by grants from the National Natural Science Foundation of China (grants \#41371057 and \#41401012). The authors are grateful to Dr. Renquan Zhang and anonymous reviewers for their constructive comments and suggestions in improving the manuscript.

\section{Appendix A. Supplementary material}

Supplementary data associated with this article can be found, in the online version, at http://dx.doi.org/10.1016/j.jseaes.2016.05. 025.

\section{References}

Aeschbach-Hertig, W., 2005. A comment on "Helium sources in passive margin aquifers-new evidence for a significant mantle ${ }^{3} \mathrm{He}$ source in aquifers with unexpectedly low in situ ${ }^{3} \mathrm{H} /{ }^{4} \mathrm{He}$ production" by M. C. Castro. Earth Planet. Sci. Lett. 240, 827-829. http://dx.doi.org/10.1016/j.epsl.2005.09.052.

Aggarwal, P.K., Araguas-Araguas, L., Choudhry, M., van Duren, M., Froehlich, K., 2014. Lower groundwater ${ }^{14} \mathrm{C}$ age by atmospheric $\mathrm{CO}_{2}$ uptake during sampling and analysis. Groundwater 52, 20-24.

Banner, J.L., Wasserburg, G.J., Dobson, P.F., Carpenter, A.B., Moore, C.H., 1989 Isotopic and trace element constraints on the origin and evolution of saline groundwaters from central Missouri. Geochim. Cosmochim. Acta 53, 383-398.

Bethke, C.M., Johnson, T.M., 2002. Paradox of groundwater age. Geology 30, $107-$ 110.

Bethke, C.M., Johnson, T.M., 2008. Groundwater age and groundwater age dating. Annu. Rev. Earth Planet. Sci. 36, 121-152.

Brandi, G.P., Ceccarelli, A., Di Paola, G.M., Fengzhong, L., Pizzi, G., 1986. Model approach to the management of the Tianjin hydrothermal field, China Geothermics 15, 639-655. http://dx.doi.org/10.1016/0375-6505(86)90076-3.

Cao, C., Cai, F., Li, Y., Zheng, Y., Wu, C., Lu, H., Bao, J., Xu, Y., 2013a. Characteristics of the submarine topography and its profile type of the coast of China. Acta Geol. Sin. (Engl. Ed.) 87, 1724-1742. http://dx.doi.org/10.1111/1755-6724.12172.

Cao, G., Zheng, C., Scanlon, B.R., Liu, J., Li, W., 2013b. Use of flow modeling to assess sustainability of groundwater resources in the North China Plain. Water Resour Res. 49, 159-175. http://dx.doi.org/10.1029/2012WR011899.

Cardenas, M.B., 2007. Potential contribution of topography-driven regional groundwater flow to fractal stream chemistry: residence time distribution analysis of Tóth flow. Geophys. Res. Lett. 34, L5403.

Castro, M.C., Goblet, P., 2005. Calculation of ground water ages-a comparative analysis. Ground Water 43, 368-380.

Chen, L., Ma, T., Du, Y., Yang, J., Liu, L., Shan, H., Liu, C., Cai, H., 2014. Origin and evolution of formation water in North China Plain based on hydrochemistry and stable isotopes $\left({ }^{2} \mathrm{H},{ }^{18} \mathrm{O},{ }^{37} \mathrm{Cl}\right.$ and $\left.{ }^{81} \mathrm{Br}\right)$. J. Geochem. Explor. 145, 250-259. http:// dx.doi.org/10.1016/j.gexplo.2014.07.006.

Chen, M., Xu, Z., 1986. Groundwater systems of the Yellow River alluvial plain, North China. IAHS Publ. 163, 243-297.

Chen, M., 1988. Geothermics of North China (in Chinese). Science Press, Beijing, p. 218.

Chen, M., Deng, X., 1990. The map of geothermal gradient of Cenozoic sediments cover in the North China Plain and its brief explanation. Sci. Geol. Sin. 3, 269277 (in Chinese with English abstract).

Chen, Z., Nie, Z., Zhang, Z., Qi, J., Nan, Y., 2005. Isotopes and sustainability of ground water resources, North China Plain. Ground Water 43, 485-493.

Chen, Z., Qi, J., Zhang, Z., 2010. The Application of Isotope Hydrogeology Method in the Northern Typical Basins. Science Press, Beijing, p. 461 (in Chinese).

China Geological Survey (CGS), 2009. Investigation and Assessment of Sustainable Utilization of Groundwater Resources in the North China Plain. Geological Publishing House, Beijing, p. 471 (in Chinese). 
Cornaton, F., Perrochet, P., 2006. Groundwater age, life expectancy and transit time distributions in advective-dispersive systems: 1. Generalized reservoir theory. Adv. Water Resour. 29, 1267-1291.

Currell, M., Gleeson, T., Dahlhaus, P., 2016. A new assessment framework for transience in hydrogeological systems. Groundwater 54, 4-14. http://dx.doi. org/10.1111/gwat.12300.

Delsman, J.R., Hu-a-ng, K.R.M., Vos, P.C., de Louw, P.G.B., Oude Essink, G.H.P. Stuyfzand, P.J., Bierkens, M.F.P., 2014. Paleo-modeling of coastal saltwater intrusion during the Holocene: an application to the Netherlands. Hydrol. Earth Syst. Sci. 18, 3891-3905. http://dx.doi.org/10.5194/hess-18-3891-2014.

Deming, D., Sass, J.H., Lachenbruch, A.H., De Rito Robert, F., 1992. Heat flow and subsurface temperature as evidence for basin-scale ground-water flow, North Slope of Alaska. Geol. Soc. Am. Bull. 104, 528-542.

Dong, Y., He, M., Jiang, S., Wu, S., Jiang, S., 2002. Chloride-36 age study for deep groundwater of Quaternary sediments, Hebei Plain. Earth Sci. 27, 105-109 (in Chinese with English abstract).

Duffy, C.J., Al-Hassan, S., 1988. Groundwater circulation in a closed desert basin: topographic scaling and climatic forcing. Water Resour. Res. 24, 1675-1688. http://dx.doi.org/10.1029/WR024i010p01675.

Edmunds, W.M., 2007. Groundwater as an archive of climatic and environmental change. In: Aggarwal, P.K., Gat, J.R., Froelich, F.O. (Eds.), Isotopes in the wate cycle, Past, Present and Future of a Developing Science. IAEA/Springer, Dordrecht, p. 381.

Engesgaard, P., Molson, J., 1998. Direct simulation of ground water age in the Rabis Creek Aquifer, Denmark. Ground Water 36, 577-582.

Forster, C., Smith, L., 1988. Groundwater flow systems in mountainous terrain: 2. Controlling factors. Water Resour. Res. 24, 1011-1023.

Foster, S., Garduno, H., Evans, R., Olson, D., Tian, Y., Zhang, W., Han, Z., 2004 Quaternary aquifer of the North China Plain-assessing and achieving groundwater resource sustainability. Hydrogeol. J. 12, 81-93.

Freeze, R.A., Witherspoon, P.A., 1967. Theoretical analysis of regional groundwater flow: 2. Effect of water-table configuration and subsurface permeability variation. Water Resour. Res. 3, 623-634. http://dx.doi.org/10.1029/ WR003i002p00623.

Garven, G., 1995. Continental-scale groundwater flow and geologic processes. Annu. Rev. Earth Planet. Sci. 23, 89-118.

Gillespie, J., Nelson, S.T., Mayo, A.L., Tingey, D.G., 2012. Why conceptual groundwater flow models matter: a trans-boundary example from the arid Great Basin, western USA. Hydrogeol. J. 20, 1133-1147.

Gleeson, T., Manning, A.H., 2008. Regional groundwater flow in mountainous terrain: three-dimensional simulations of topographic and hydrogeologic controls. Water Resour. Res. 44, W10403. http://dx.doi.org/10.1029/ 2008WR006848.

Goderniaux, P., Davy, P., Bresciani, E., de Dreuzy, J., Le Borgne, T., 2013. Partitioning a regional groundwater flow system into shallow local and deep regional flow compartments. Water Resour. Res. 49, 2274-2286. http://dx.doi.org/10.1002/ wrcr.20186.

Goode, D.J., 1996. Direct simulation of groundwater age. Water Resour. Res. 32 289-296.

Gupta, I., Wilson, A.M., Rostron, B.J., 2015. Groundwater age, brine migration, and large-scale solute transport in the Alberta Basin, Canada. Geofluids 15, 608-620. http://dx.doi.org/10.1111/gfl.12131.

Haitjema, H.M., Mitchell-Bruker, S., 2005. Are water tables a subdued replica of the topography? Ground Water 43, 781-786.

Hecht-Méndez, J., Molina Giraldo, N., Blum, P., Bayer, P., 2010. Evaluating MT3DMS for heat transport simulation of closed geothermal systems. Ground Water 48 $741-756$.

Kennedy, C.D., Genereux, D.P., 2007. C-14 groundwater age and the importance of chemical fluxes across aquifer boundaries in confined cretaceous aquifers of North Carolina, USA. Radiocarbon 49, 1181-1203.

Kreuzer, A.M., von Rohden, C., Friedrich, R., Chen, Z.Y., Shi, J.S., Hajdas, I., Kipfer, R. Aeschbach-Hertig, W., 2009. A record of temperature and monsoon intensity over the past $40 \mathrm{kyr}$ from groundwater in the North China Plain. Chem. Geol. 259, 168-180.

Lavastre, V., Salle, C.L.G.L., Michelot, J., Giannesini, S., Benedetti, L., Lancelot, J., Lavielle, B., Massault, M., Thomas, B., Gilabert, E., Bourlès, D., Clauer, N., Agrinier, P., 2010. Establishing constraints on groundwater ages with ${ }^{36} \mathrm{Cl},{ }^{14} \mathrm{C},{ }^{3} \mathrm{H}$, and noble gases: a case study in the eastern Paris basin, France. Appl. Geochem. 25 , 123-142. http://dx.doi.org/10.1016/j.apgeochem.2009.10.006.

Lazear, G., 2006. Evidence for deep groundwater flow and convective heat transport in mountainous terrain, Delta County, Colorado, USA. Hydrogeol. J. 14, 15821598. http://dx.doi.org/10.1007/s10040-006-0058-8.

Lemieux, J.M., Sudicky, E.A., 2010. Simulation of groundwater age evolution during the Wisconsinian glaciation over the Canadian landscape. Environ. Fluid Mech. 10, 91-102.

Lemieux, J.M., Sudicky, E.A., Peltier, W.R., Tarasov, L., 2008. Simulating the impact of glaciations on continental groundwater flow systems: 2. Model application to the Wisconsinian glaciation over the Canadian landscape. J. Geophys. Res. Earth Surf. 113 (F3), F03018.

Li, X., Zhou, A., Liu, Y., Ma, T., Liu, C., Liu, L., Yang, J., 2012. Stable isotope geochemistry of dissolved chloride in relation to hydrogeology of the strongly exploited Quaternary aquifers, North China Plain. Appl. Geochem. 27, 20312041. http://dx.doi.org/10.1016/j.apgeochem.2012.05.013.

Liu, C., Wang, H., Wang, P., 1987. A study of the groundwater origin in Hebei Plain with isotopic method. In: Isotope applications in hydrology in Asia and the Pacific, proceedings of a regional executive management seminar on isotope techniques in water resources development and management and a regional workshop on isotopes hydrology for Asia and the Pacific, Beijing, pp. 216-230.

Liu, C., Wang, P., Zhou, L., Jiang, S., Jiang, S., Guo, H., Huang, L., 1993. Cl dating of quaternary groundwater in Hebei Plain. Hydrogeol. Eng. Geol. 6, 35-38 (in Chinese with English abstract).

Massoudieh, A., Sharifi, S., Solomon, D.K., 2012. Bayesian evaluation of groundwater age distribution using radioactive tracers and anthropogenic chemicals. Water Resour. Res. 48, W9529.

Mazor, E., 2003. Chemical and Isotopic Groundwater Hydrology. CRC Press, p. 453.

McCallum, J.L., Cook, P.G., Simmons, C.T., 2015. Limitations of the use of environmental tracers to infer groundwater age. Groundwater 53, 56-70. http://dx.doi.org/10.1111/gwat.12237.

Michael, H.A., Voss, C.I., 2009. Controls on groundwater flow in the Bengal Basin of India and Bangladesh: regional modeling analysis. Hydrogeol. J. 17, $1561-1577$.

Minissale, A., Borrini, D., Montegrossi, G., Orlando, A., Tassi, F., Vaselli, O., Huertas, A. D., Yang, J., Cheng, W., Tedesco, D., Poreda, R., 2008. The Tianjin geothermal field (north-eastern China): water chemistry and possible reservoir permeability reduction phenomena. Geothermics 37, 400-428. http://dx.doi.org/10.1016/ j.geothermics.2008.03.001

Morrissey, S.K., Clark, J.F., Bennett, M., Richardson, E., Stute, M., 2010. Groundwater reorganization in the Floridan aquifer following Holocene sea-level rise. Nat. Geosci. 3, 683-687.

Newman, B.D., Osenbruck, K., Aeschbach-Hertig, W., Kip, S.D., Cook, P., Rozanski, K., Kipfer, R., 2010. Dating of 'young' groundwaters using environmental tracers: advantages, applications, and research needs. Isot. Environ. Health Stud. 46, 259-278.

Pang, Z., Li, Y., Yang, F., Duan, Z., 2012. Geochemistry of a continental saline aquifer for $\mathrm{CO}_{2}$ sequestration: the Guantao formation in the Bohai Bay Basin, North China. Appl. Geochem. 27, 1821-1828.

Plummer, L.N., Eggleston, J.R., Andreasen, D.C., Raffensperger, J.P., Hunt, A.G., Casile, G.C., 2012. Old groundwater in parts of the upper Patapsco aquifer, Atlantic Coastal Plain, Maryland, USA: evidence from radiocarbon, chlorine-36 and helium-4. Hydrogeol. J. 20, 1269-1294.

Ren, M., Shi, Y., 1986. Sediment discharge of the Yellow River (China) and its effect on the sedimentation of the Bohai and the Yellow Sea. Cont. Shelf Res. 6, 785810.

Rousseau-Gueutin, P., Love, A.J., Vasseur, G., Robinson, N.I., Simmons, C.T., Marsily, G., 2013. Time to reach near-steady state in large aquifers. Water Resour. Res. 49, 6893-6908. http://dx.doi.org/10.1002/wrcr.20534.

Sanford, W.E., Buapeng, S., 1996. Assessment of a groundwater flow model of the Bangkok basin, Thailand, using carbon-14-based ages and paleohydrology. Hydrogeol. J. 4, 26-40.

Sanford, W.E., Pope, J.P., 2010. Current challenges using models to forecast seawater intrusion: lessons from the Eastern Shore of Virginia, USA. Hydrogeol. J. 18, 7393.

Sanford, W., 2011. Calibration of models using groundwater age. Hydrogeol. J. 19, $13-16$

Schaller, M.F., Fan, Y., 2009. River basins as groundwater exporters and importers: implications for water cycle and climate modeling. J. Geophys. Res.: Atmos. 114, D4103.

Schwartz, F.W., Sudicky, E.A., McLaren, R.G., Park, Y.J., Huber, M., Apted, M., 2010. Ambiguous hydraulic heads and ${ }^{14} \mathrm{C}$ activities in transient regional flow. Ground Water $48,366-379$.

Stewart, M.K., 2012. A 40-year record of carbon-14 and tritium in the Christchurch groundwater system, New Zealand: dating of young samples with carbon-14. J. Hydrol. 430-431, 50-68.

Sun, A., Niu, S., 2000. The mantle plume evolution and its geothermal effect-deep tectonic setting of geothermal anomaly in North China. Acta Geosci. Sin. 21, 182-189 (in Chinese with English abstract).

Sun, J., Zhou, J., Liu, C., Zhou, A., Zhang, J., Li, Y., Song, H., 2006. Preliminary study of ${ }^{4} \mathrm{He}$ age for groundwater in Hebei Plain: a case of Mancheng-Renqiu section. Geol. Sci. Technol. Inform. 25, 77-81 (in Chinese with English abstract).

Sun, S., Xie, J., Li, G., Qiu, C., 1982. Hydrogen and oxyten isotopic composition and genesis of the ground water in Jizhong depression. Oil Gas Geol. 3, 240-250 (in Chinese with English abstract).

Tóth, J., 1963. A theoretical analysis of groundwater flow in small drainage basins. J. Geophys. Res. 68, 4795-4812.

Tóth, J., 1995. Hydraulic continuity in large sedimentary basins. Hydrogeol. J. 3, 416.

Tóth, J., 1999. Groundwater as a geologic agent: an overview of the causes, processes, and manifestations. Hydrogeol. J. 7, 1-14.

Tóth, J., 2009. Gravitational Systems of Groundwater Flow: Theory, Evaluation, Utilization. Cambridge University Press, p. 297.

von Rohden, C., Kreuzer, A., Chen, Z., Kipfer, R., Aeschbach-Hertig, W. 2010. Characterizing the recharge regime of the strongly exploited aquifers of the North China Plain by environmental tracers. Water Resour. Res. 46, W05511.

Wang, J., Zhou, J., 1992. The Environmental Impact of Low-Temperature Geothermal Resources and its Use in the North China Plain: Take Hejian Area as an Example. Seismological Press, Beijing, p. 70 (in Chinese).

Wang, P., 1990. The ice-age China sea-status and problems. Quat. Sci. 2, 111-124 (in Chinese with English abstract).

Wang, X., Li, H., Jiao, J.J., Barry, D.A., Li, L., Luo, X., Wang, C., Wan, L., Wang, X., Jiang, X., Ma, Q., Qu, W., 2015. Submarine fresh groundwater discharge into Laizhou Bay comparable to the Yellow River flux. Sci. Rep. 5, 8814. http://dx.doi.org/ $10.1038 /$ srep08814. 
Wei, W., Aeschbach-Hertig, W., Chen, Z., 2015. Identification of He sources and estimation of He ages in groundwater of the North China Plain. Appl. Geochem. 63, 182-189. http://dx.doi.org/10.1016/j.apgeochem.2015.08.010.

Wen, D., Zhang, F., Zhang, E., Wang, C., Han, S., Zheng, Y., 2013. Arsenic, fluoride and iodine in groundwater of China. J. Geochem. Explor. 135, 1-21.

Winter, T.C., 1999. Relation of streams, lakes, and wetlands to groundwater flow systems. Hydrogeol. J. 7, 28-45.

Xia, Z., 1984. The accumulation and dispersion of the salt in the soil at the hillock, slope and low land in central Hopei. Geogr. Res. 3, 44-52 (in Chinese with English abstract).

Xu, Q.H., Wu, C., Yang, X.L., Zhang, N.J., 1996. Palaeochannels on the North China Plain: relationships between their development and tectonics. Geomorphology 18, 27-35.

Yang, Y., Xu, T., 2004. Hydrocarbon habitat of the offshore Bohai Basin, China. Mar. Pet. Geol. 21, 691-708. http://dx.doi.org/10.1016/j.marpetgeo.2004.03.008.

Yao, Z., 1995. Paleoclimate record of geothermal water for last $0.03 \mathrm{Ma}$ in north China. Earth Sci. - J. China Univ. Geosci. 20, 383-388 (in Chinese with English abstract).

Ye, H., Shedlock, K.M., Hellinger, S.J., Sclater, J.G., 1985. The North China Basin: an example of a Cenozoic rifted intraplate basin. Tectonics 4, 153-169. http://dx. doi.org/10.1029/TC004i002p00153.

Zhang, B., Wang, X., Lin, J., 2006. Isotope characteristics of the geothermal water of the Tianjin geothermal field. West China Explor. Eng. 18, 85-88 (in Chinese).

Zhang, J., Cai, H., Liu, C., Zhou, A., Yan, Z., 2005. Characteristics of helium isotopes of groundwater in the Quaternary System in the Hebei Plain, North China. Earth Sci. Front. 12, 7-13 (in Chinese with English abstract).

Zhang, R., Liang, X., Jin, M., 2013. The evolution of groundwater flow systems in the Quaternary of Hebei Plain since the Last Glacial Maximum. Earth Sci. Front. 20, 217-226 (in Chinese with English abstract).
Zhang, X., 1990. Geochemistry and genesis of geothermal water in Tianjin city. Bull. Inst. Hydrogeol. Eng. Geol. CAGS 6, 1-24 (in Chinese with English abstract).

Zhang, Z., Payne, B.R., 1987. Environmental isotope study related to groundwate age, flow system and saline water origin in Quaternary aquifers of North China Plain. In: Isotope applications in Hydrology in Asia and the Pacific, Proceedings of A Regional Executive Management Seminar on Isotope Techniques in Water Resources Development and Management and A Regional Workshop on sotopes Hydrology for Asia and the Pacific, Beijing, pp. 6-22.

Zhang, Z., Shen, Z. Xue, Y., Ren, F. 2000. Groundwater Environment Evolution in the North China Plain. Geological Publishing House, Beijing (in Chinese)

Zhang, Z., Shi, D., Ren, F., Yin, Z., Sun, J., Zhang, C., 1997. Evolution of quaternary groundwater system in North China Plain. Sci. China Ser. D - Earth Sci. 40, $276-$ 283.

Zheng, C., Wang, P.P., 1999. MT3DMS: a modular three-dimensional multispecies model for simulation of advection, dispersion and chemical reactions of contaminants in groundwater systems; documentation and user's guide, Contract Report SERDP-99-1. U.S. Army Engineer Research and Development Center, Vicksburg, MS.

Zheng, C., Hill, M.C., Cao, G., Ma, R., 2012. MT3DMS: model use, calibration, and validation. Trans. ASABE 55, 1549-1559.

Zhou, L., Liu, J., Saito, Y., Liu, J.P., Li, G., Liu, Q., Gao, M., Qiu, J., 2014. Fluvial system development and subsequent marine transgression in Yellow River (Huanghe) delta and its adjacent sea regions during last glacial maximum to early Holocene. Cont. Shelf Res. 90, 117-132.

Zhou, X., Fang, B., Zhou, H.Y., Li, J., Wang, Y., 2009. Isotopes of deuterium and oxygen-18 in thermal groundwater in China. Environ. Geol. 57, 1807-1814.

Zhu, Y., Liu, S., Guo, Y., 1995. Groundwater dynamic environment evolution and its constraints in Hebei Plain. Earth Sci. - J. China Univ. Geosci. 20, 433-437 (in Chinese with English abstract). 